\title{
Pollen morphology of the Myrtaceae. Part 2: tribes Backhousieae, Melaleuceae, Metrosidereae, Osbornieae and Syzygieae
}

\author{
Andrew H. Thornhill ${ }^{\mathrm{A}, \mathrm{D}}$, Geoff S. Hope ${ }^{\mathrm{B}}$, Lyn A. Craven ${ }^{\mathrm{C}}$ and Michael D. Crisp ${ }^{\mathrm{A}}$ \\ A Division of Evolution, Ecology and Genetics, Research School of Biology, Building 116, Daley Road, \\ The Australian National University, Canberra, ACT 0200, Australia. \\ ${ }^{B}$ Department of Archaeology and Natural History, College of Asia and the Pacific, The Australian National \\ University, Canberra, ACT 0200, Australia. \\ ${ }^{\mathrm{C}}$ Australian National Herbarium, CSIRO Plant Industry, GPO Box 1600, Canberra, ACT 2601, Australia. \\ ${ }^{D}$ Corresponding author. Email: Andrew.Thornhill@anu.edu.au
}

\begin{abstract}
Pollen morphology of 16 genera and 101 species from the Myrtaceae tribes Backhousieae, Melaleuceae, Metrosidereae, Osbornieae and Syzygieae was surveyed using scanning electron microscopy (SEM) and light microscopy (LM). The most common pollen type observed in these tribes was parasyncolpate with arcuate or angular colpi, and a rugulate exine pattern. There was little size variation in observed pollen, except for larger pollen in tribe Melaleuceae. All Metrosideros pollen grains had apocolpial islands, as well as all Callistemon species viewed by LM. Choricarpia of tribe Backhousieae had pollen with a distinctive exine pattern. Dicolporate pollen were observed in two tribes, Metrosidereae (Tepualia) and Syzygieae (Acmena), and may be of systematic value. The dicolporate grains of these two genera were also easily distinguishable from each other by using size and pollen side shape as diagnostic characters. Two pollen types were observed within the genus Melaleuca, and a number of pollen types were observed within the species-rich genus Syzygium.
\end{abstract}

Received 4 July 2011, accepted 9 January 2012, published online 10 April 2012

\section{Introduction}

Tribes of the Myrtaceae subfamily Myrtoideae, namely Backhousieae, Melaleuceae, Metrosidereae, Osbornieae and Syzygieae, are found in Australia, New Zealand, New Caledonia, South-east Asia, South Pacific islands, Hawaii, southern South America and Africa. Melaleuceae and Osbornieae are sister tribes (Wilson et al. 2005), whereas sister tribes Backhousieae and Syzygieae are closely related to Metrosidereae (Biffin et al. 2010). These two groups are distantly related to each other, but the pollen of these tribes, in particular the presence of a large apocolpial island, are very similar. Previous palynological work on members of these tribes has been conducted by Pike (1956), McIntyre (1963), Gadek and Martin (1981), Patel et al. (1984), Moar (1993) and Parnell (2003). These studies have shown that pollen is oblate and parasyncolpate. Parnell (2003) investigated 57 species of Syzygium, mainly from South-east Asia, by SEM and found it difficult to separate species on the basis of pollen characters, but also noted that pollen from Jambosa-type species were larger than pollen from most other Syzygium species.

\section{Materials and methods}

Methods and terminology used in the present study are detailed in Thornhill et al. (2012a). In figures and tables, the current accepted species name is applied and the previous name appears in parentheses. The list of taxa used for the study includes previous and current accepted names to enable crossreferencing to past palynological work (Tables S1 and S2, available as Supplementary Material).

\section{Results}

Pollen descriptions

Tribe Backhousieae

Two genera are included in Backhousieae, both of which occur only in Australia. Backhousia and Choricarpia species grow in rainforest and dry forest areas of Queensland and New South Wales, and one species of Backhousia occurs in the Kimberley region of Western Australia. Pollen measurements for Backhousieae are summarised in Tables 1 and 2.

\section{Genus Backhousia}

Number of species: 10.

Distribution: eastern and north-western Australia.

Species examined: SEM - 2; LM - 2 .

Previous pollen studies: Pike (1956); Gadek and Martin (1981). 


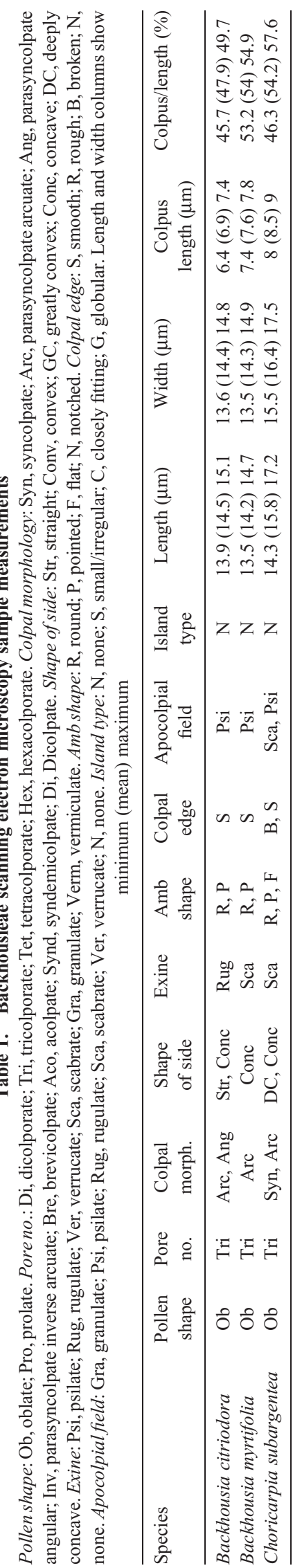

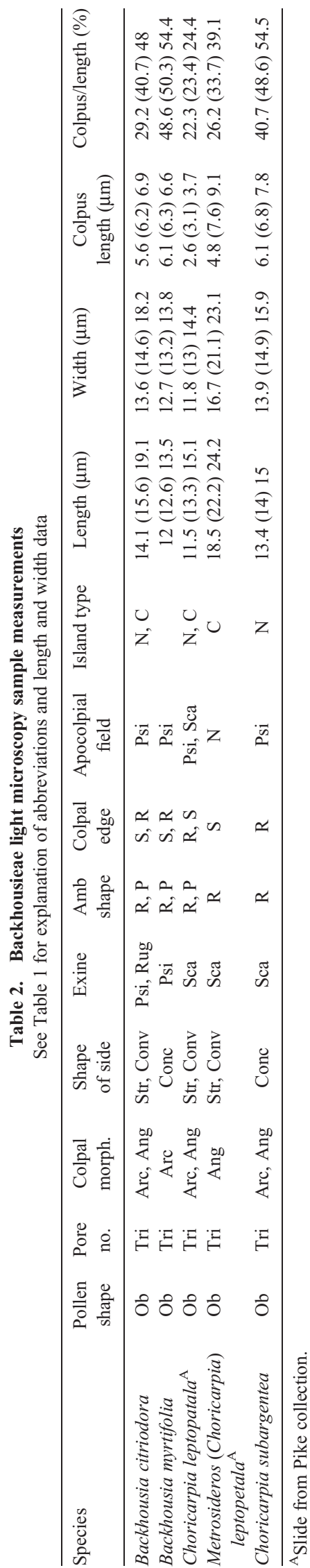


Images: SEM polar view - Fig. $1 a, b$; SEM exine pattern Fig. $2 a, b$; SEM equatorial view - Fig. $13 h$; LM polar view Fig. $3 a, b$.

SEM: Backhousia pollen were tricolporate with a rugulate or scabrate exine, partially similar to the findings of Gadek and Martin (1981). Pollen sides were concave or straight and colpal morphology was parasyncolpate with arcuate or angular colpi. Pollen ambs were round or pointed, colpal edges were smooth and the apocolpial field was psilate. Pollen length ranged from 13.5 to $15.1 \mu \mathrm{m}$. Colpus/length ratio ranged from 45.7 to $54.9 \%$.

LM: the exine of Backhousia was psilate or sometimes rugulate. Pollen sides were straight, concave or convex. Colpal morphology was parasyncolpate with arcuate, or more rarely, angular colpi. Pollen ambs were round or pointed, colpal edges were smooth or rough, and the apocolpial field was psilate. Pollen length ranged from 12 to $19.1 \mu \mathrm{m}$. Colpus/length ratio ranged from 29.23 to $54.4 \%$.

\section{Genus Choricarpia}

Number of species: 2.

Distribution: eastern Australia.

Species examined: SEM - 1; LM - 2 (3 samples).

Previous pollen studies: Pike (1956); Gadek and Martin (1981).

Images: SEM polar view - Fig. 1c; SEM exine pattern - Fig. 2c; LM polar view - Fig. $3 c-f$.
SEM: Choricarpia pollen were tricolporate with a scabrate exine. Pollen sides were deeply concave or concave and colpal morphology was syncolpate or parasyncolpate with arcuate colpi. All possible pollen amb states were scored for Choricarpia. Colpus edges were broken or sometimes smooth, and there was a scabrate or psilate apocolpial field. Pollen length ranged from 14.3 to $17.2 \mu \mathrm{m}$. Colpus/length ranged from 35.6 to $45 \%$.

LM: exine patterns of Choricarpia were scabrate. Pollen sides were straight, concave or convex and colpal morphology was parasyncolpate with arcuate or angular colpi. Pollen ambs were round or occasionally pointed, colpal edges were rough or smooth and the apocolpial field was psilate or scabrate. Closely fitting apocolpial islands were sometimes present. Pollen length ranged from 11.5 to $24.2 \mu \mathrm{m}$. Colpus/length ratio ranged from 22.3 to $54.5 \%$.

\section{Tribe Metrosidereae}

There are two genera included in Metrosidereae, both of which occur in the Malesian-Pacific region, with one species of Metrosideros occurring in South Africa. The previously recognised Mearnsia, now part of Metrosideros (Wright et al. 2000), is discussed as a separate genus in the present paper, for ease of reference to past palynology papers. All species of Metrosideros are found in rainforests, whereas the monotypic genus Tepualia occurs in marshes, bogs and river banks of Chile

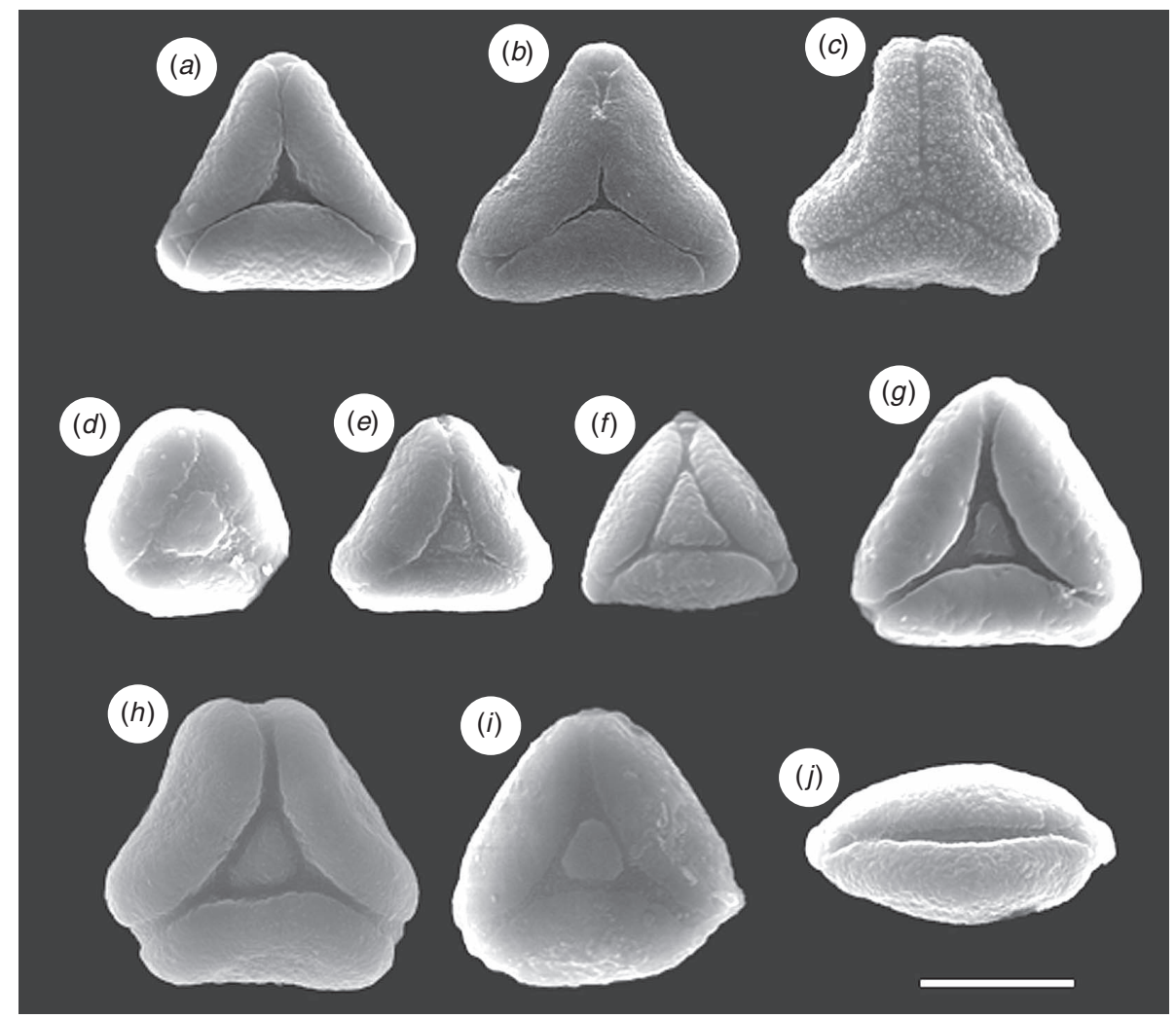

Fig. 1. Polar view of Backhousieae and Metrosidereae under scanning electron microscope. Scale bar $=10 \mu \mathrm{m}$. (a) Backhousia citriodora, (b) B. myrtifolia, (c) Choricarpia subargentea, (d) Mearnsia cordata, (e) Metrosideros carminea, (f) M. diffusa, (g) M. macropus, (h) M. nervulosa, (i) M. nitida and (j) Tepualia stipularis. 


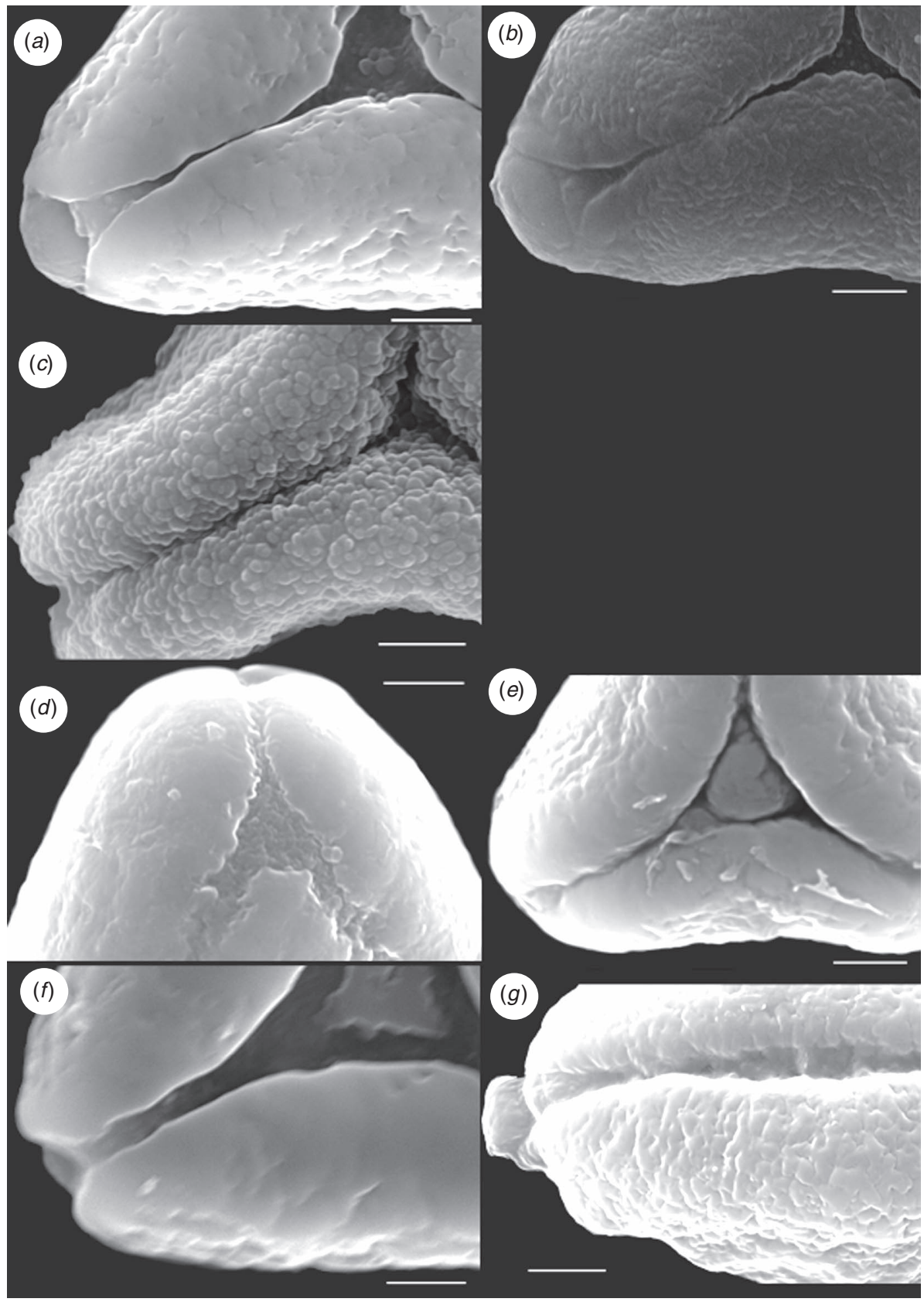

Fig. 2. Exine pattern of Backhousieae and Metrosidereae under scanning electron microscope. Scale bar $=2 \mu \mathrm{m}$. (a) Backhousia citriodora, (b) B. myrtifolia, (c) Choricarpia subargentea, (d) Mearnsia cordata, (e) Metrosideros carminea, $(f)$ M. macrocarpus and (g) Tepualia stipularis.

and Argentina in South America. Pollen measurements for Metrosidereae are summarised in Tables 5 and 6.

\section{Genus Mearnsia}

Number of species: $\sim 18$.

Distribution: Malesia.

Species examined: SEM -1; LM -1.

Previous pollen studies: Pike (1956).

Images: SEM polar view - Fig. $1 d$; SEM exine pattern - Fig. $2 d$; LM polar view - Fig. $3 g$.
SEM: Mearnsia pollen were tricolporate with a psilate/rugulate exine. Pollen sides were convex and colpal morphology was parasyncolpate with angular colpi. Pollen ambs were round or flat, colpal edges were rough and the apocolpial field was psilate or scabrate. Closely fitting polar islands were present at the polar regions of all grains. Pollen length ranged from 12.6 to $13.7 \mu \mathrm{m}$. Colpus/length ratio ranged from 27.4 to $32 \%$.

$L M$ : the exine of Mearnsia was psilate. Pollen sides were convex and colpal morphology was parasyncolpate with angular colpi. Pollen ambs were round, colpus edges were smooth, and all pollen had closely fitting apocolpial islands. Pollen length ranged 

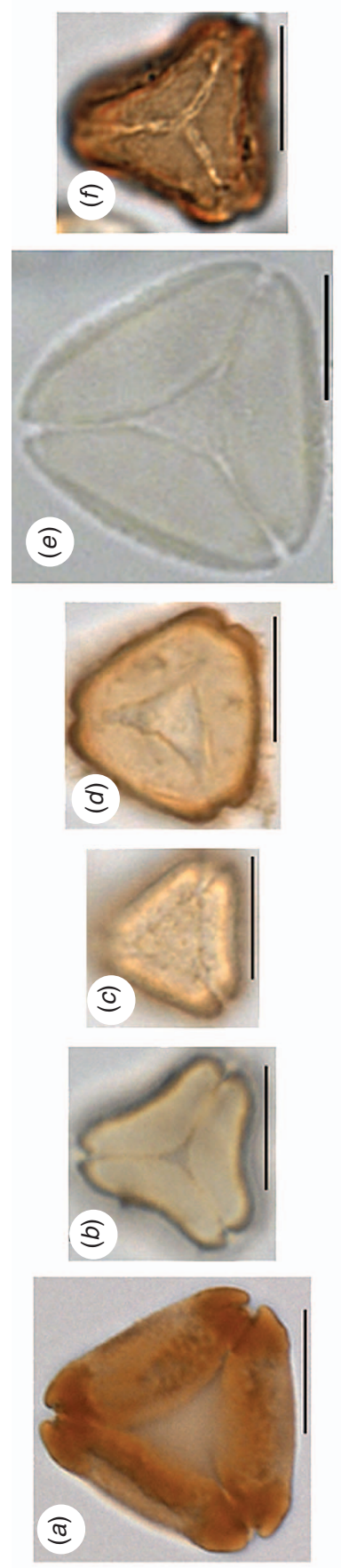
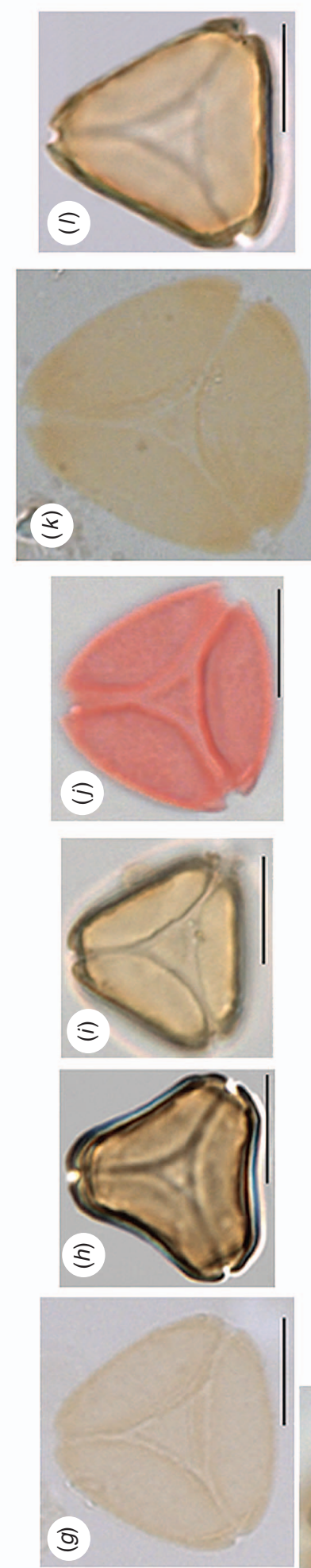

ह

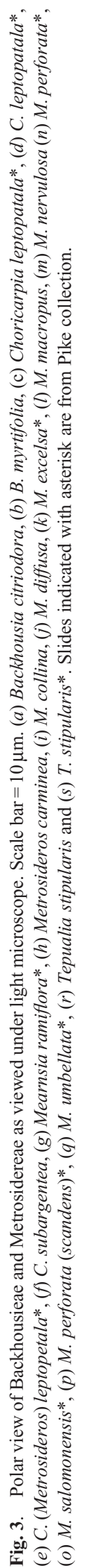


from 19.2 to $21.6 \mu \mathrm{m}$. Colpus/length ratio ranged from 31.3 to $35.4 \%$.

\section{Genus Metrosideros}

Number of species: $\sim 74$.

Distribution: New Caledonia, New Zealand, Hawaii, New Guinea, south Pacific Islands and South Africa.

Species examined: SEM -5; LM - 10 .

Previous pollen studies: Pike (1956); McIntyre (1963); Gadek and Martin (1981); Moar (1993).

Images: SEM polar view - Fig. 1e-i; SEM exine pattern Fig. $2 e, f$; SEM equatorial view - Fig. 13i; LM polar view Fig. $3 h-q$.

SEM: Metrosideros pollen were tricolporate. The majority of grains had a rugulate exine, and a lesser number possessed a vermiculate or verrucate/scabrate exine. Pollen sides were concave, convex or straight, and colpal morphology was consistently parasyncolpate with angular colpi. Pollen ambs were round, pointed or sometimes flat, colpal edges were smooth or rough and the apocolpial field was either psilate, scabrate or not visible because of apocolpial island presence. Most observed apocolpial islands were closely fitting, but small irregular islands were observed in M.carminea, M. macropus and M. nervulosa, and apocolpial islands have been observed in all previous palynology studies of Metrosideros. Pollen length ranged from 11.1 to $20.9 \mu \mathrm{m}$. Colpus/length ratio ranged from 27.3 to $46.5 \%$.

LM: the exine of Metrosideros was psilate or at times scabrate. Most grains were tricolporate, except for some dicolporate grains of M.umbellata. Pollen sides were straight or convex or intermittently greatly convex. Colpal morphology was consistently parasyncolpate with angular colpi, except for M. carminea and M. macropus which had arcuate colpi. Pollen ambs were primarily round, or less often pointed, and colpal edges were smooth. The majority of observed apocolpial islands were closely fitting, although small irregular islands were observed on M. salomonensis grains. Pollen length ranged from 13 to $30.6 \mu \mathrm{m}$. Colpus/length ratio ranged from 26.8 to $42.8 \%$.

\section{Genus Tepualia}

Number of species: 1.

Distribution: Argentina and Chile.

Species examined: SEM - 1; LM - 1 (2 samples).

Previous pollen studies: Pike (1956); Zhou and Heusser (1996).

Images: SEM polar view - Fig. 1j; SEM exine pattern - Fig. $2 g$; LM polar view - Fig. $3 r, s$.

SEM: Tepualia pollen were dicolporate with a rugulate or verrucate exine. Pollen sides were convex and colpal morphology was dicolpate with the colpi fused together to give the appearance of one functional unit. Pollen ambs were round or pointed, colpal edges were smooth and the apocolpial field was psilate or scabrate. Pollen length ranged from 10.6 to $11.8 \mu \mathrm{m}$. The colpus/length ratio was $100 \%$.

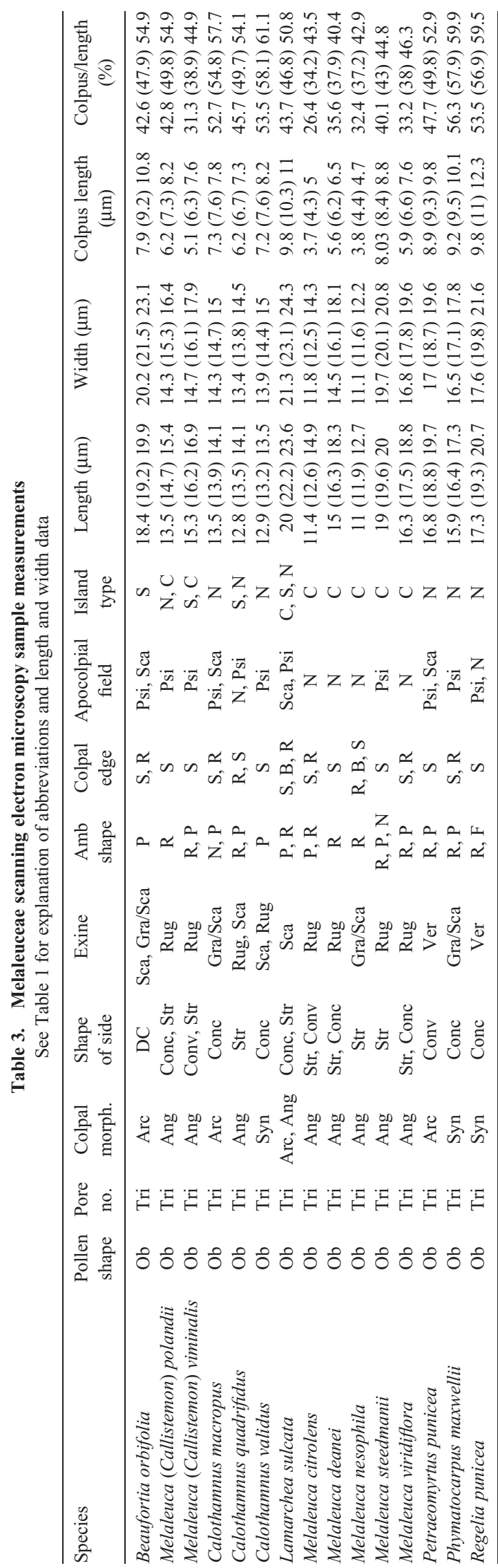




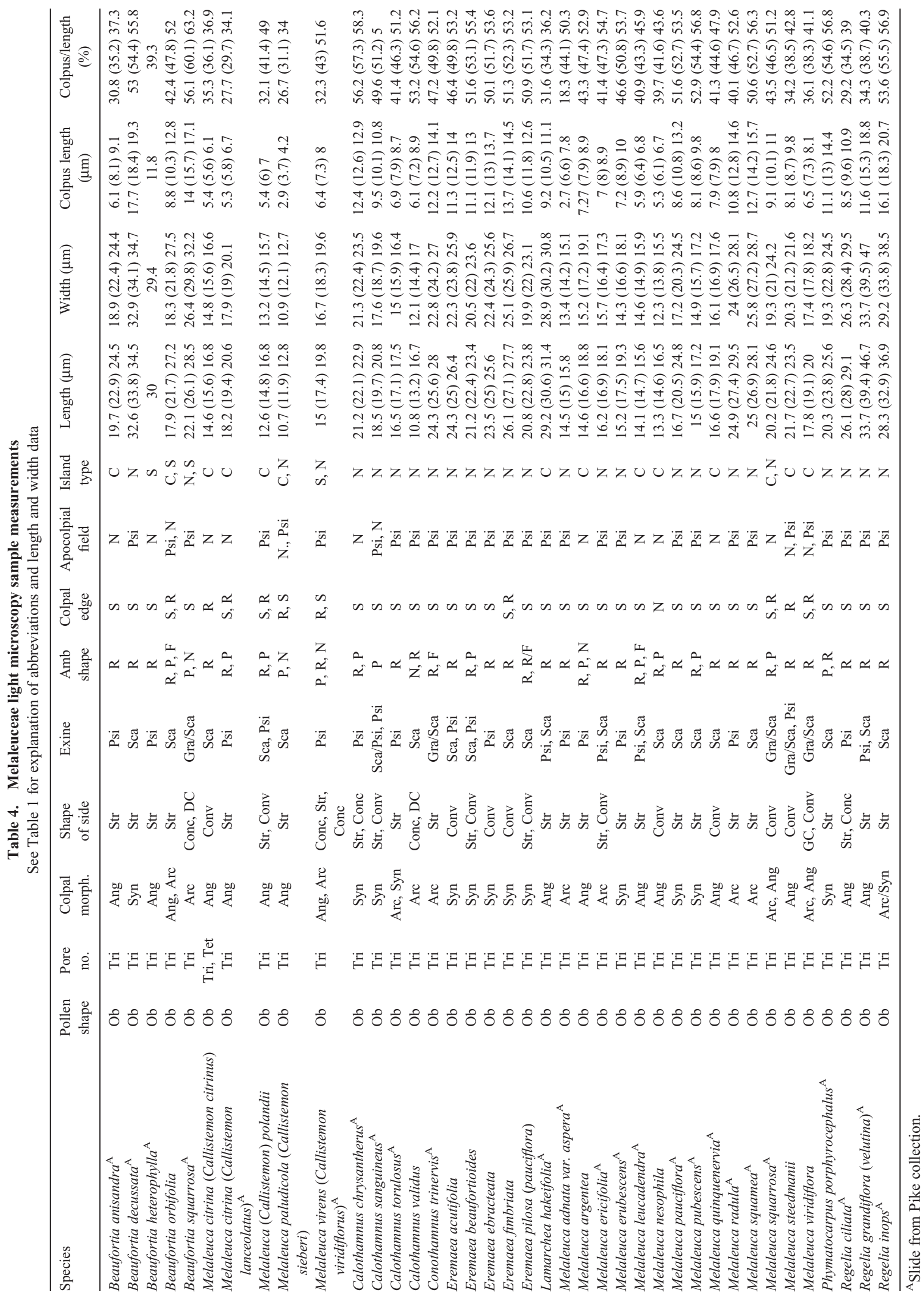


LM: the exine of Tepualia was psilate. Pollen sides were convex and colpal morphology was dicolpate. Pollen ambs were round, colpi edges were smooth, and the apocolpial field was psilate. Pollen length ranged from 11.8 to $12.5 \mu \mathrm{m}$. The colpus/length ratio was $100 \%$.

\section{Tribe Melaleuceae}

Representatives of Melaleuceae are predominantly found in Australia, but also occur in Malesia, Lord Howe Island and New Caledonia. There were nine genera recognised in tribe Melaleuceae; however, recent phylogenetic work has shown that all genera are nested within Melaleuca, which now encompasses 2380 species (Edwards et al. 2010). Melaleuceae taxa occur in many vegetation types, especially heathlands, woodlands and swamp. For ease of cross referencing to past palynology studies, we have retained the former generic names in the present paper. Pollen measurements for Melaleuceae are summarised in Tables 3 and 4.

\section{Genus Beaufortia}

Number of species: 21.

Distribution: south-western Australia.

Species examined: SEM - 1; LM - 5 .

Previous pollen studies: Pike (1956).

Images: SEM polar view - Fig. 4a; SEM exine pattern - Fig. 5a; SEM equatorial view - Fig. $7 a$; LM polar view - Fig. $8 a-f$.

SEM: Beaufortia pollen were tricolporate with a scabrate to granulate/scabrate exine. Pollen sides were deeply concave and the colpal morphology was parasyncolpate with arcuate colpi. Small irregular islands occurred on every grain. Pollen ambs were pointed, colpal edges were smooth or rough and the apocolpial field was psilate or scabrate. Pollen length ranged from 18.4 to $19.9 \mu \mathrm{m}$. Colpus/length percentage ranged from $42.6 \%$ to $54.9 \%$.

LM: exine patterns of Beaufortia were either psilate, scabrate or granulate/scabrate. Most observed grains had straight sides, except for B. squarrosa which had either concave or deeply concave sides. Colpal morphology was predominantly parasyncolpate with angular colpi, but $B$. squarrosa had arcuate colpi, and $B$. decussata had syncolpate pollen. Pollen ambs were round, or less often pointed, flat or notched. Colpal edges were smooth and the apocolpial field was psilate, or not visible because of a closely fitting apocolpial island. Apocolpial islands were present on the pollen of all species except for $B$. decussata. Pollen length ranged from 17.9 to $34.5 \mu \mathrm{m}$. Colpus/length ratio ranged from $30.8 \%$ to $63.2 \%$.

\section{Genus Callistemon}

Number of species: 39.

Distribution: Australia.

Species examined: SEM - 2; LM - 5 .

Previous pollen studies: Pike (1956); Patel et al. (1984); Boyd (1992).

Images: SEM polar view-Fig. 4b, $c$; SEM exine pattern-Fig. 5b; LM polar view - Fig. $8 g-l$.
SEM: Callistemon grains were tricolporate with a rugulate exine. Pollen sides were concave, convex or straight and colpal morphology was parasyncolpate with angular colpi. Pollen ambs were round or pointed, colpal edges were smooth and the apocolpial field was psilate. Some pollen lacked an apocolpial island but the majority of grains possessed a closely fitting or sometimes small irregular polar island. Pollen length ranged from 13.5 to $16.9 \mu \mathrm{m}$. Colpus/length ratio ranged from $31.3 \%$ to $54.9 \%$.

LM: the exine of Callistemon was scabrate or psilate. Pollen sides were straight or convex or occasionally concave. Some pollen of $C$. citrinus was tetracolporate. Colpal morphology was parasyncolpate with angular colpi, except for some grains of C.viridiflorus which had arcuate colpi. Pollen ambs were round, pointed or sometimes notched, colpal edges were smooth or rough, and the apocolpial field was either psilate or not visible because of an apocolpial island. All examined slides had pollen with closely fitting apocolpial islands, except for C.viridiflorus which had small irregular islands. Pollen length ranged from 10.7 to $20.6 \mu \mathrm{m}$. Colpus/length ratio ranged from $26.7 \%$ to $51.6 \%$.

\section{Genus Calothamnus}

Number of species: 40.

Distribution: south-western Australia.

Species examined: SEM - 3; LM - 4 .

Previous pollen studies: Pike (1956); Patel et al. (1984).

Images: SEM polar view - Fig. 4d-f; SEM exine pattern Fig. $5 c, d$; SEM equatorial view - Fig. $7 b$; LM polar view Fig. $8 m-p$.

SEM: Calothamnus pollen were tricolporate with a rugulate or scabrate exine. Pollen sides were concave or straight and colpal morphology was parasyncolpate with arcuate or angular colpi or syncolpate. Pollen ambs were pointed, round or notched, colpus edges were smooth or round and the apocolpial field pattern was psilate or scabrate. Most pollen grains lacked an apocolpial island, except for those of C.quadrifidus which had small irregular islands. Pollen length ranged from 12.8 to $14.1 \mu \mathrm{m}$. Colpus/length ratio ranged from $45.7 \%$ to $61.1 \%$.

LM: exine patterns of Calothamnus were psilate or scabrate. Pollen sides were straight or sometimes convex or concave. Colpal morphology was mainly syncolpate or occasionally parasyncolpate with arcuate colpi. Pollen ambs were round or pointed, colpal edges were smooth and the apocolpial field was psilate. Pollen length ranged from 10.8 to $22.9 \mu \mathrm{m}$. Colpus/length ratio ranged from 41.4 to $58.3 \%$.

\section{Genus Conothamnus}

Number of species: 3.

Distribution: south-western Australia.

Species examined: SEM - not observed; LM - 1 .

Previous pollen studies: Pike (1956).

Images: LM polar view - Fig. $8 q$. 


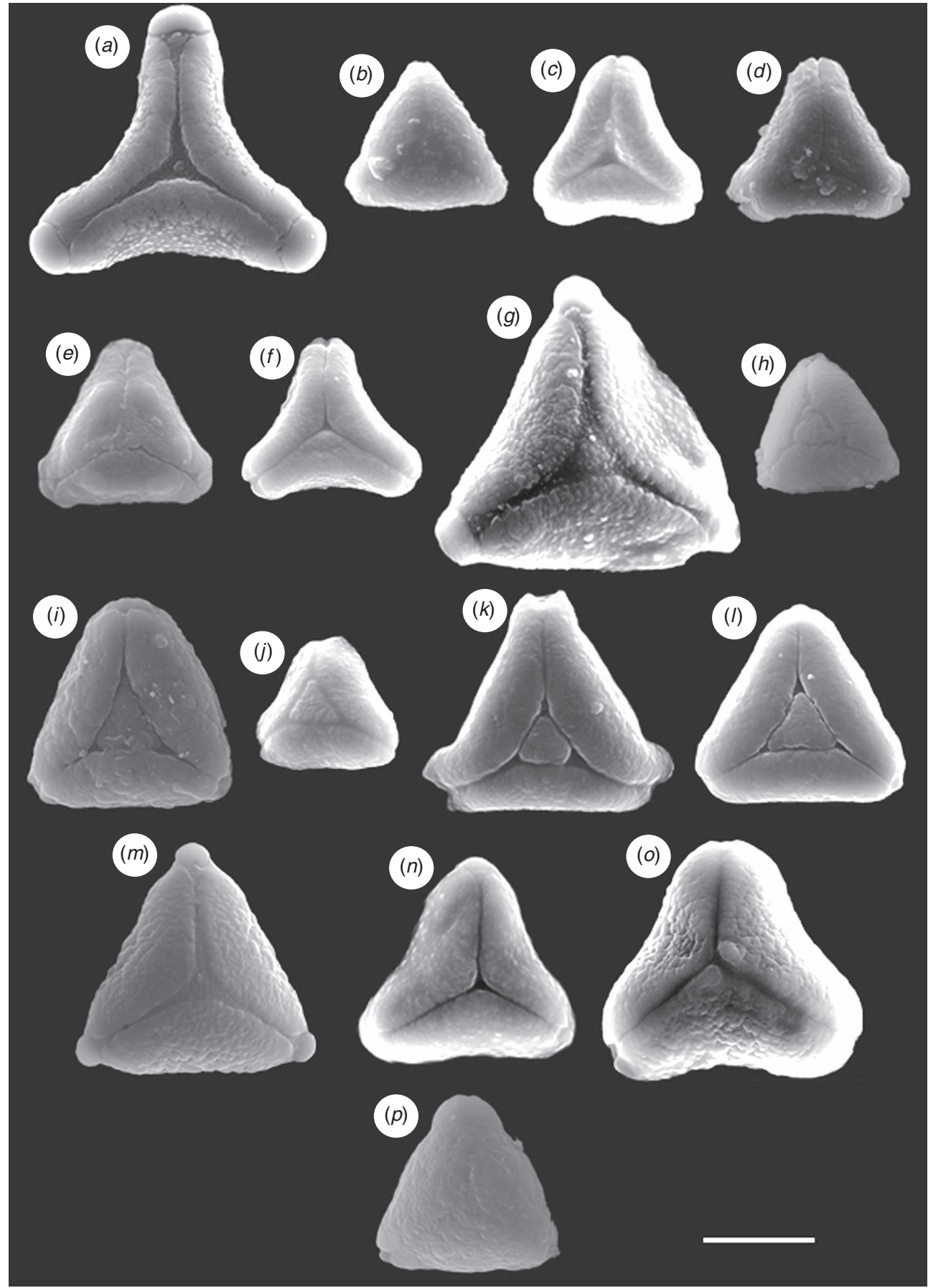

Fig. 4. Polar view of Melaleuceae and Osbornieae under scanning electron microscope. Scale bar $=10 \mu \mathrm{m}$. (a)Beaufortia orbifolia, (b) Melaleuca (Callistemon) polandii, (c) M. (Callistemon) viminalis, (d) Calothamnus macrocarpus, (e) C. quadrifidus, (f) C. validus, $(g)$ Lamarchea sulcata, (h) Melaleuca citrolens, (i) M. deanei, (j) M. nesophila, (k) M. steedmanii, (l) M. viridiflora, (m) Petraeomyrtus punicea, (n) Phymatocarpus maxwellii, (o) Petraeomyrtus (Regelia) punicea and ( $p$ ) Osbornia octodonta.

LM: Conothamnus pollen were tricolporate with a granulate/ scabrate exine. Pollen sides were straight and colpal morphology was parasyncolpate with arcuate colpi. Pollen ambs were notched or round, colpus edges were smooth and the apocolpial field was psilate. Pollen length ranged from 24.3 to $28 \mu \mathrm{m}$. Colpus/length ratio ranged from 47.2 to $52.1 \%$.

\section{Genus Eremaea}

Number of species: 15.

Distribution: south-western Australia.

Species examined: SEM - not observed; LM - 5 .

Previous pollen studies: Pike (1956); Patel et al. (1984). 


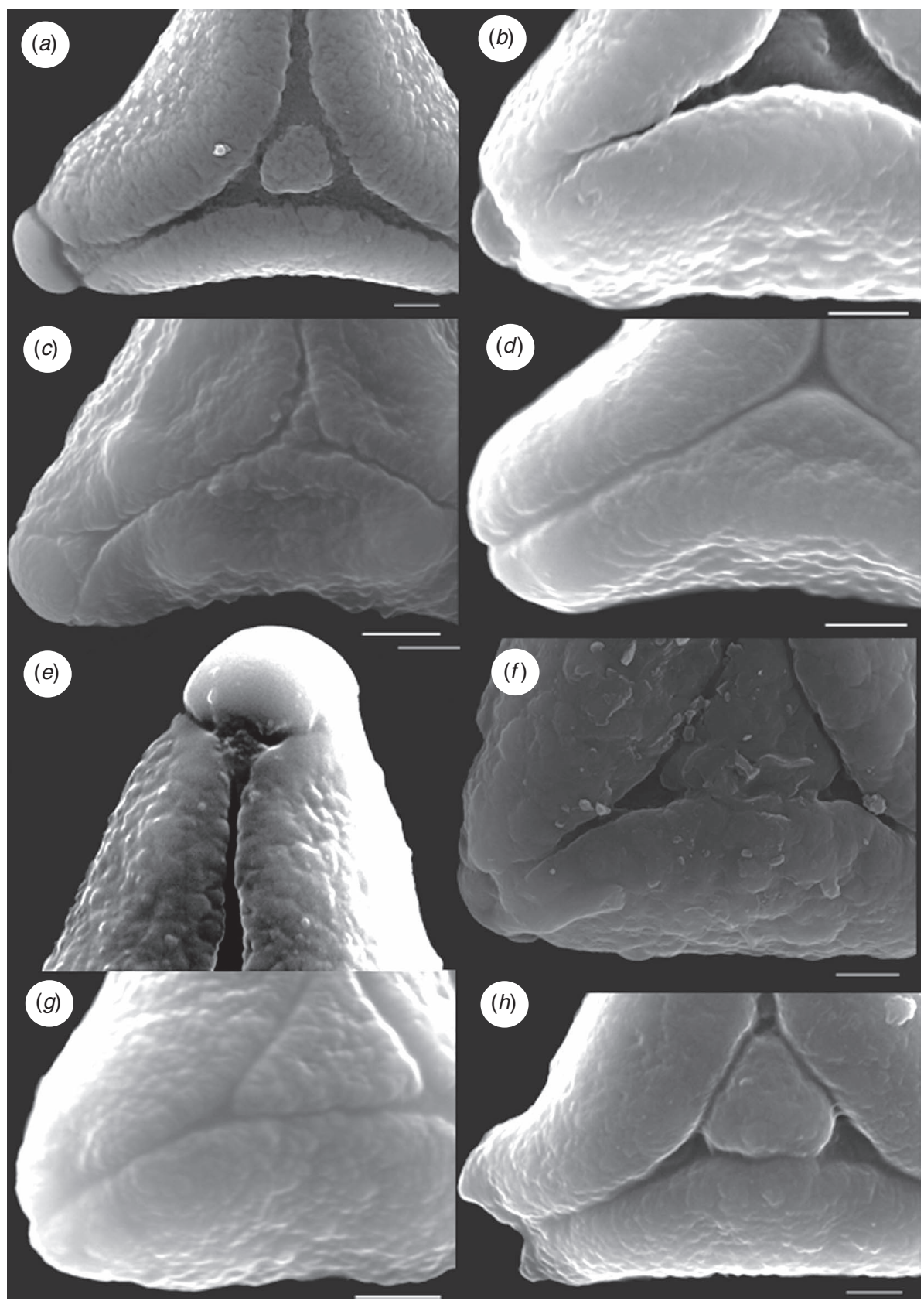

Fig. 5. Exine pattern of Melaleuceae under scanning electron microscope. Scale bar $=2 \mu \mathrm{m}$. (a) Beaufortia orbifolia, (b) Melaleuca (Callistemon) polandii, (c) Calothamnus quadrifidus, $(d)$ C. validus, (e) Lamarchea sulcata, $(f)$ Melaleuca deanei, $(g)$ M. nesophila and $(h)$ M. steedmanii.

Images: LM polar view - Fig. $8 r-w$.

LM: Eremaea pollen were tricolporate with a scabrate or psilate exine. Pollen sides were convex or straight and the colpal morphology was syncolpate. Pollen ambs were round or less often pointed or flat, colpal edges were smooth and the apocolpial field was psilate. Pollen length ranged from 20.8 to $27.7 \mu \mathrm{m}$. Colpus/length ratio ranged from 46.4 to $55.4 \%$.

\section{Genus Lamarchea}

Number of species: 2.
Distribution: south-western Australia.

Species examined: SEM - 1; LM - 1 .

Previous pollen studies: Pike (1956); Boyd (1992).

Images: SEM polar view - Fig. $4 g$; SEM exine pattern - Fig. 5e; LM polar view - Fig. $8 x$.

SEM: Lamarchea pollen were tricolporate with a verrucate/ scabrate exine. Pollen sides were concave or straight and colpal morphology was parasyncolpate with arcuate or angular colpi. Pollen ambs were pointed or round, colpal edges were smooth, broken or rough and the apocolpial field was scabrate or 
psilate. Closely fitting or small irregular islands were noted, but some Lamarchea grains did not have an island. Pollen length ranged from 20 to $26.6 \mu \mathrm{m}$. Colpus/length ratio ranged from 43.7 to $50.8 \%$.
LM: exine patterns of Lamarchea were psilate or scabrate. Pollen sides were straight and the colpal morphology was parasyncolpate with angular colpi. Pollen ambs were round, colpal edges were smooth and the apocolpial field was psilate.

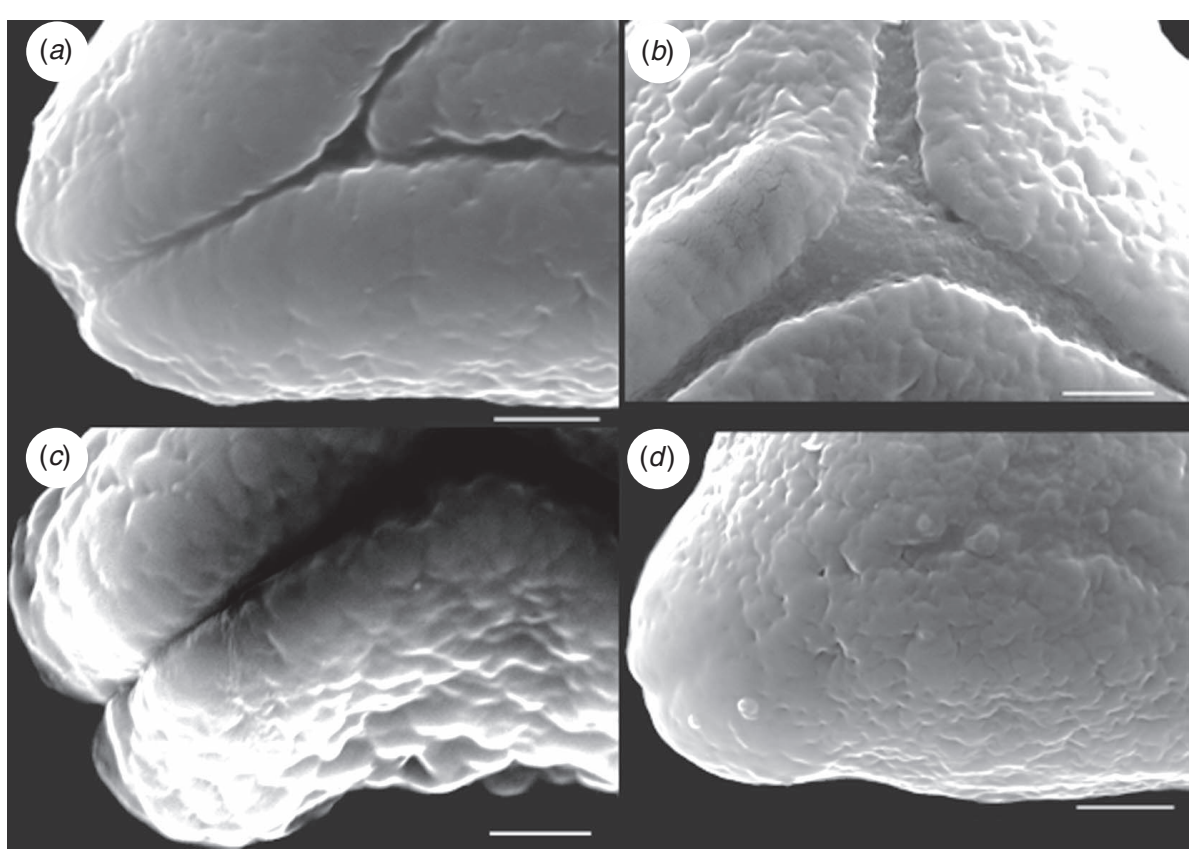

Fig. 6. Exine pattern of Melaleuceae and Osbornieae under scanning electron microscope. Scale bar $=2 \mu \mathrm{m}$. (a) Melaleuca viridiflora, (b) Petraeomyrtus punicea, (c) P. (Regelia) punicea and (d) Osbornia octodonta.

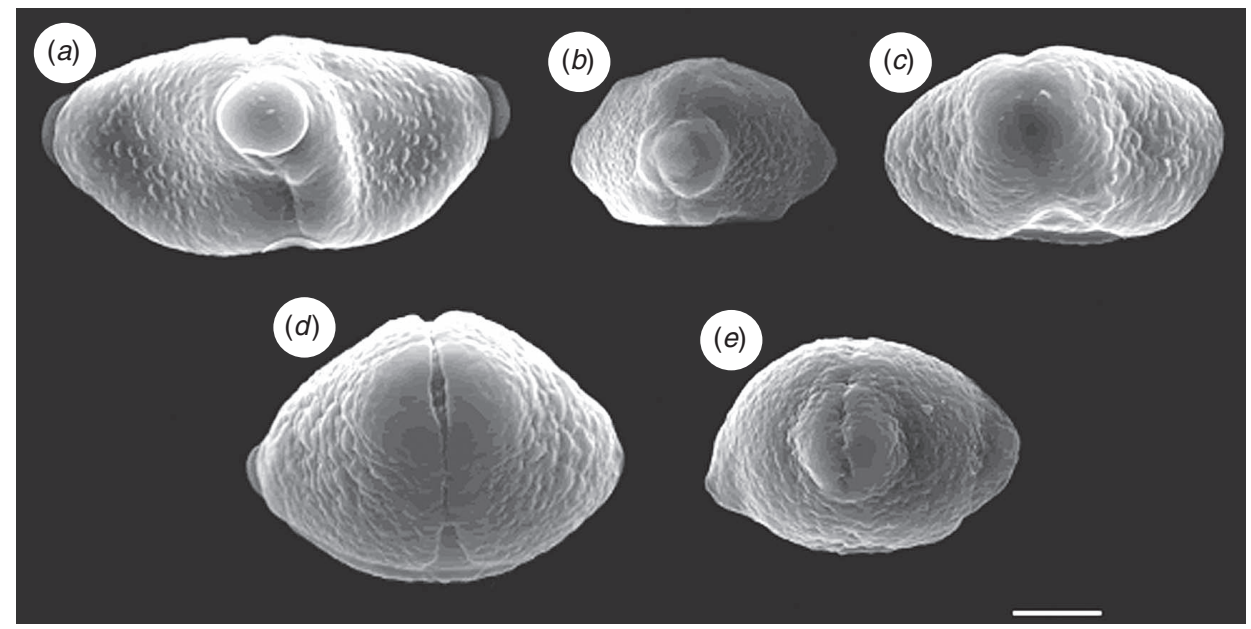

Fig. 7. Equatorial view of Melaleuceae and Osbornieae under scanning electron microscope. Scale bar $=5 \mu$ m. (a) Beaufortia orbifolia, (b) Calothamnus quadrifidus, (c) Melaleuca viridiflora, (d) Petraeomyrtus punicea and (e) Osbornia octodonta.

Fig. 8. Polar view of Melaleuceae as viewed under light microscope. Scale bar $=10 \mu \mathrm{m} .(a)$ Beaufortia anisandra*, (b) B. decussata*, (c) B. heterophylla*, (d) B. orbifolia, (e)B. squarrosa*, (f) B. squarrosa*, $(g)$ Melaleuca citrina (Callistemon citrinus), $(h)$ M. citrina (Callistemon citrinus), $(i)$ M. citrina (Callistemon lanceolatus), (j) M. (Callistemon) polandii, (k) M. paludicola (Callistemon sieberi), $(l)$ M. virens (Callistemon viridiflorus)*, $(m)$ Calothamnus chrysantherus*, (n) C. sanguineus*, (o) C. torulosus*, (p) C. validus, (q) Conothamnus trinervis*, $(r)$ Eremaea acutifolia, $(s)$ E. beaufortioides, $(t)$ E. beaufortioides, (u) E. ebracteata, (v) Eremaea fimbriata, (w) E. pilosa, (x) Lamarchea hakeifolia*, (y) Melaleuca adnata var. aspera*, (z) M. argentea, (aa) M. ericifolia*, (bb) M. erubescens*, (cc) M. leucadendra*,(dd) M. nesophila, (ee) M. pauciflora*, (ff) M. pubescens* and (gg) M. quinquenervia*. Slides indicated with asterisk are from Pike collection. 

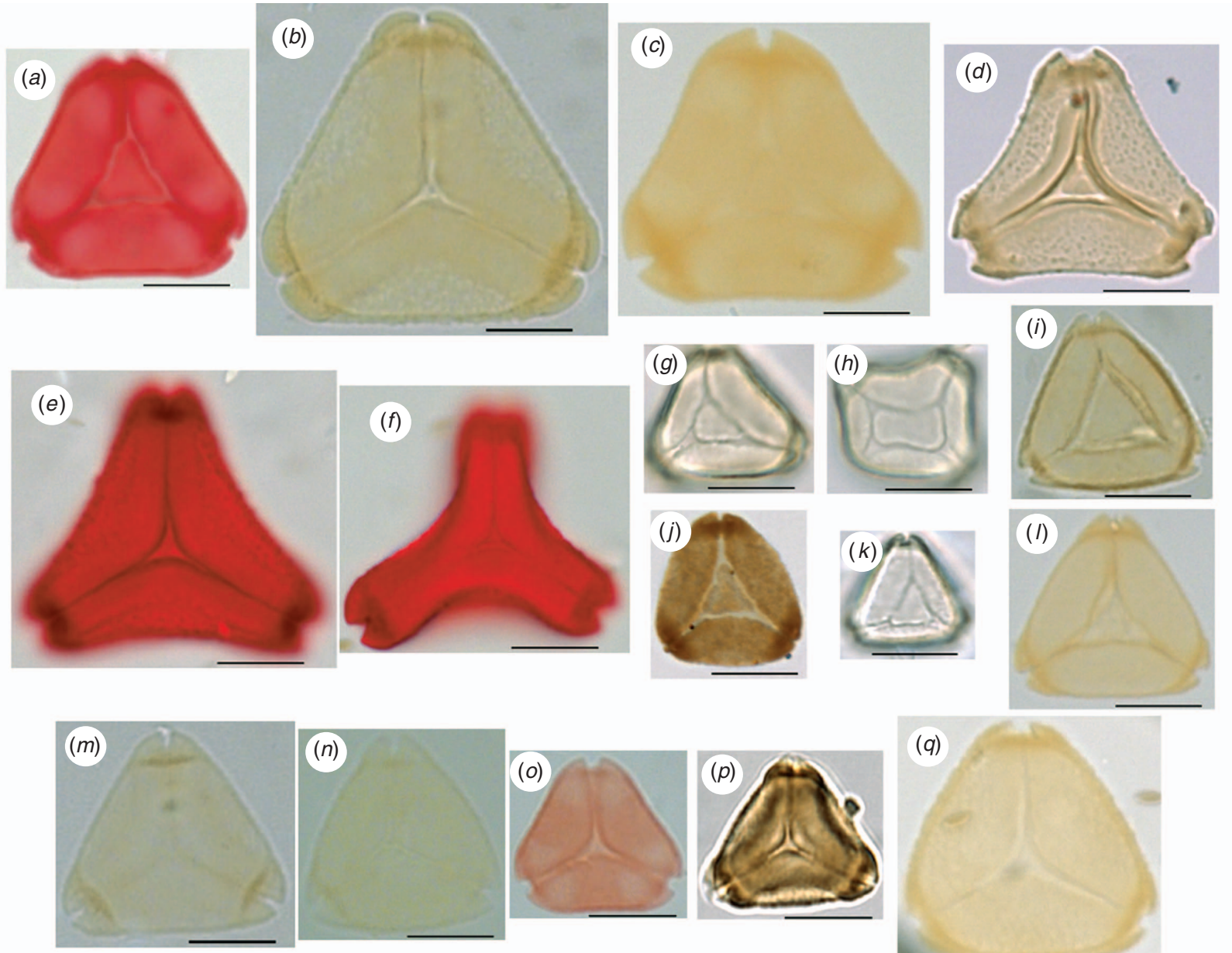

(q)
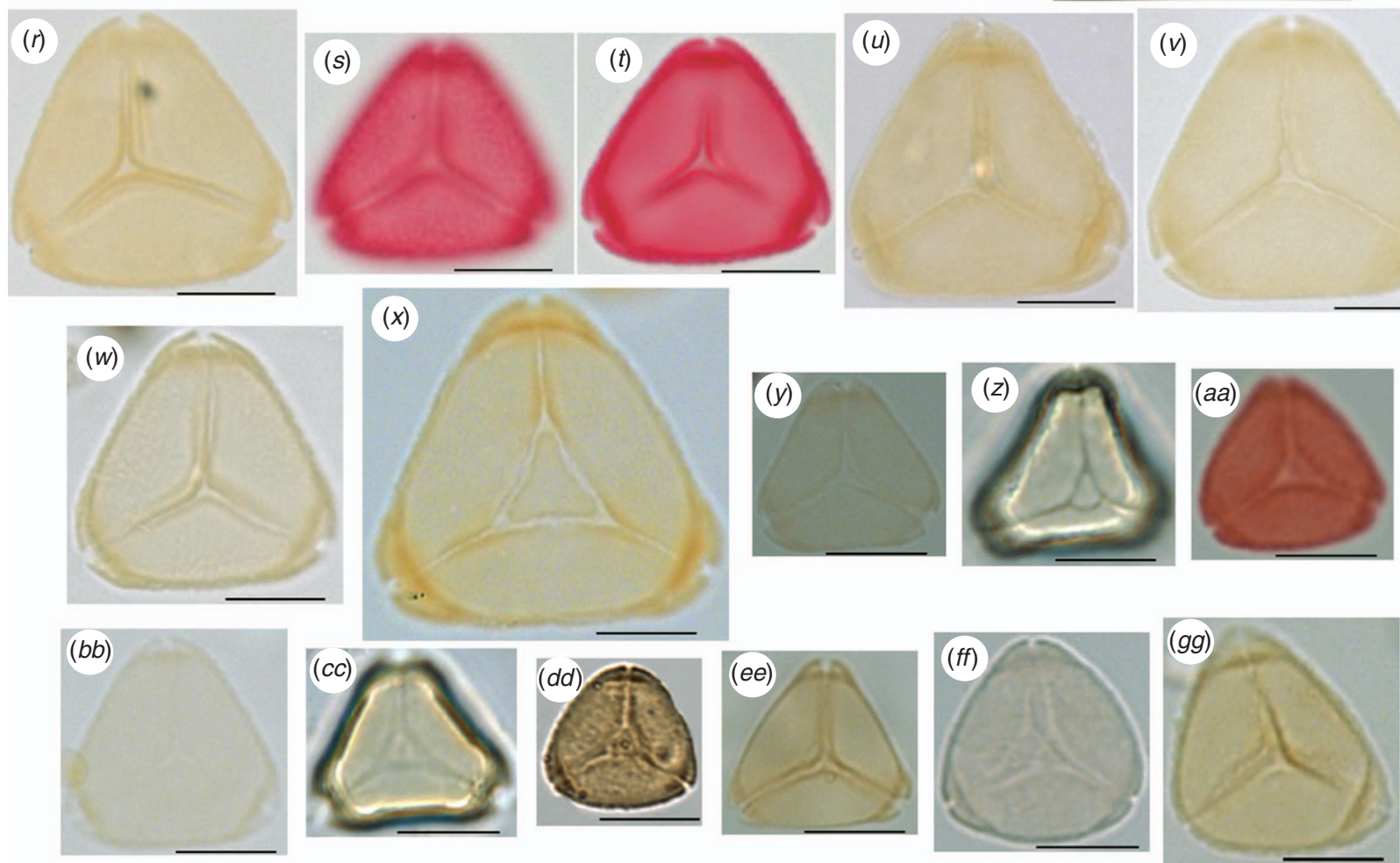

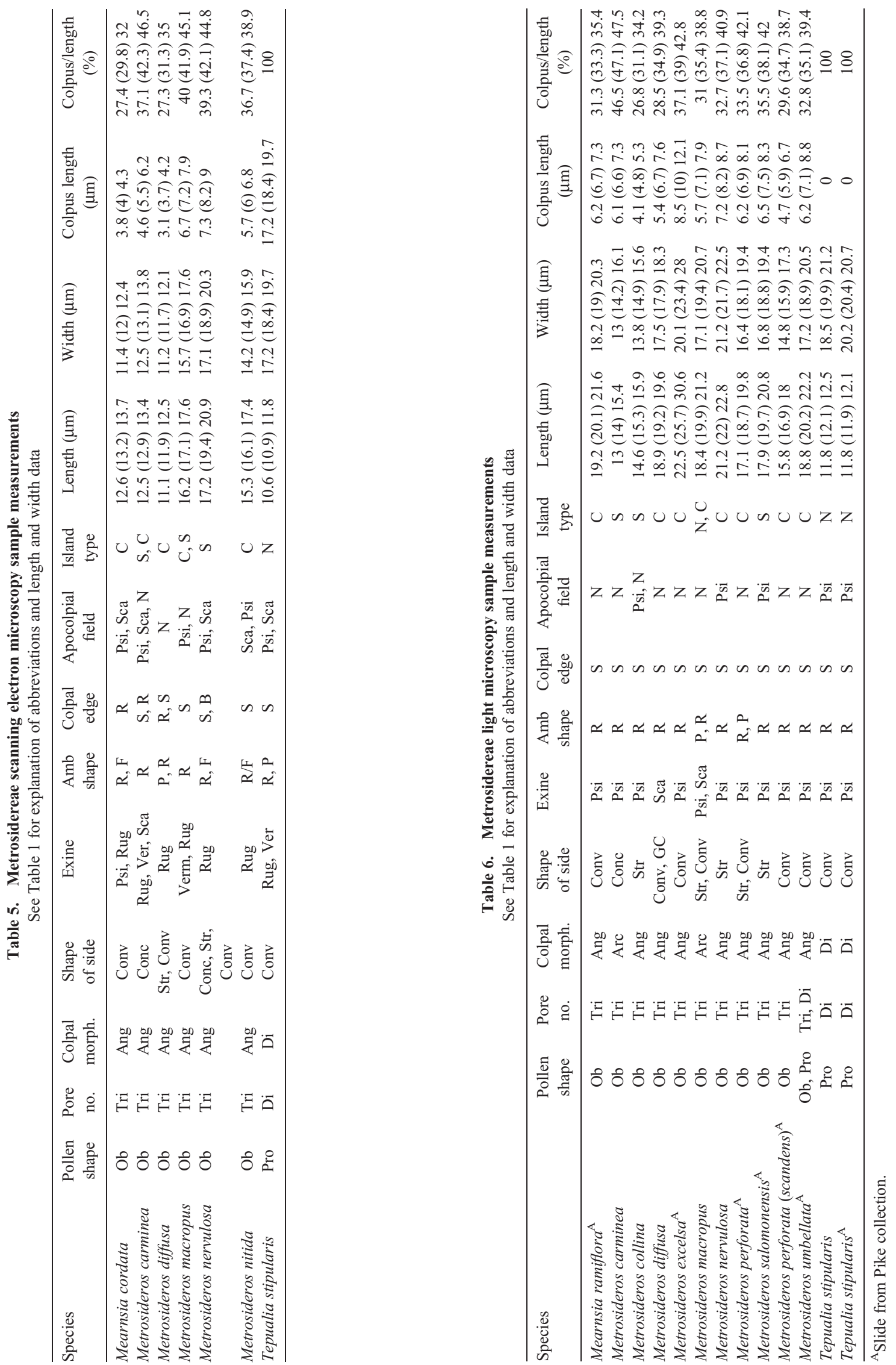

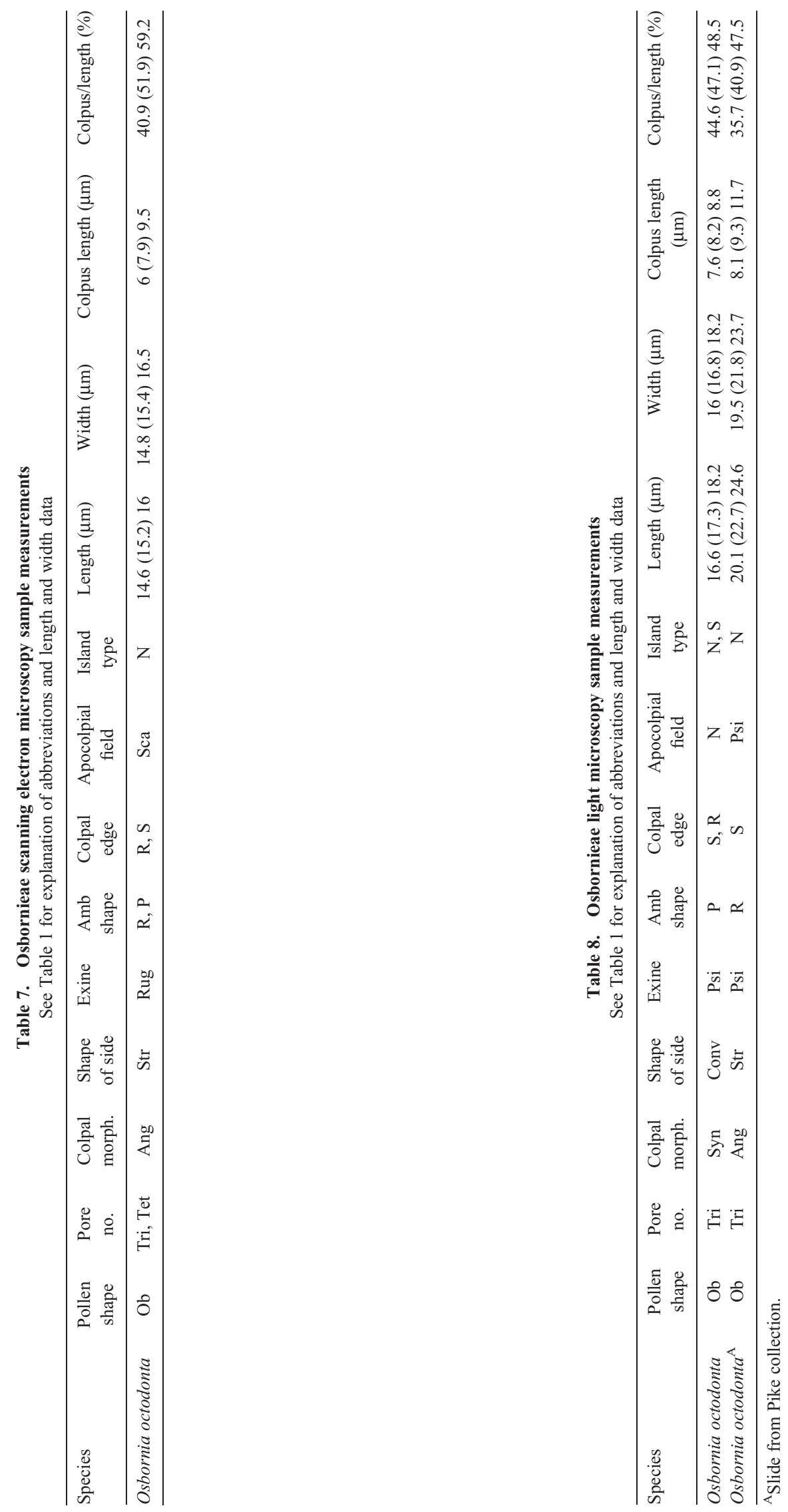
Closely fitting apocolpial islands were observed on all grains. Pollen length ranged from 30 to $31.4 \mu \mathrm{m}$. Colpus/length ratio ranged from 31.6 to $36.2 \%$.

\section{Genus Melaleuca}

Number of species: 251.

Distribution: Australia, Malesia, and New Caledonia.

Species examined: SEM - 5; LM - 14.

Previous pollen studies: Pike (1956); Martin (1973); Patel et al. (1984); Boyd (1992); Chalson and Martin (1995).

Images: SEM polar view - Fig. 4h-l; SEM exine pattern Figs $5 f-h, 6 a$; SEM equatorial view - Fig. $7 c$; LM polar view - Figs $8 y-g g, 9 a-f$.

SEM: Melaleuca pollen were tricolporate with a rugulate exine, except for M. nesophila grains that had a granulate/scabrate exine. Pollen sides were straight, or less commonly convex or concave, and the colpal morphology was consistently parasyncolpate with angular colpi. Pollen ambs were round or pointed, or less commonly notched, colpal edges were smooth or occasionally rough and the apocolpial field was not visible or psilate. Closely fitting apocolpial islands were present for pollen of all observed Melaleuca species. Pollen length ranged from 11 to $20 \mu \mathrm{m}$. Colpus/length ratio ranged from $26.4 \%$ to $46.3 \%$.

LM: exine patterns of Melaleuca were scabrate, psilate or, less often, granulate/scabrate. Pollen sides were straight or convex, and the colpal morphology was parasyncolpate with angular or arcuate colpi, or occasionally syncolpate. Pollen ambs were round or less commonly pointed or flat. Colpal edges were smooth or rough and the apocolpial field was psilate. Pollen length ranged from 13.3 to $29.5 \mu \mathrm{m}$. Colpus/length ratio ranged from 34.2 to $56.8 \%$.

\section{Genus Petraeomyrtus}

Number of species: 1.

Distribution: northern Australia.

Species examined: SEM - 1; LM - not observed.

Previous pollen studies: none.

Images: SEM polar view - Fig. $4 m$; SEM exine pattern - Fig. $6 b$; SEM equatorial view - Fig. $7 d$.

SEM: Petraeomyrtus pollen were tricolporate with a verrucate exine. Pollen sides were convex and colpal morphology was parasyncolpate with arcuate colpi. Pollen ambs were round or pointed, colpal edges were smooth and the apocolpial field was psilate or scabrate. Pollen length ranged from 16.8 to $19.7 \mu \mathrm{m}$. Colpus/length ratio ranged from 47.7 to $52.9 \%$.

\section{Genus Phymatocarpus}

Number of species: 3.

Distribution: south-western Australia.

Species examined: SEM - 1; LM - 1 .

Previous pollen studies: Pike (1956).

Images: SEM polar view - Fig. $4 n$; LM polar view - Fig. $9 g$.

SEM: Phymatocarpus pollen were tricolporate with a granulate/ scabrate exine. Pollen sides were concave and colpal morphology was syncolpate. Pollen ambs were round or pointed, colpal edges

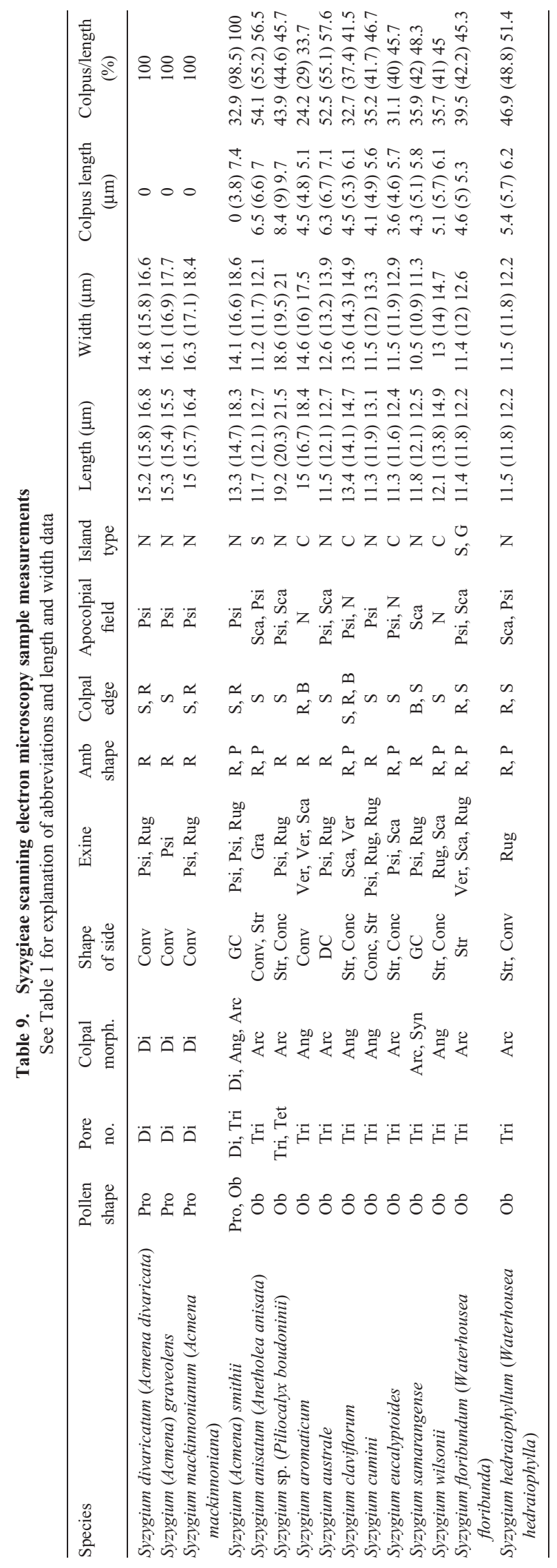




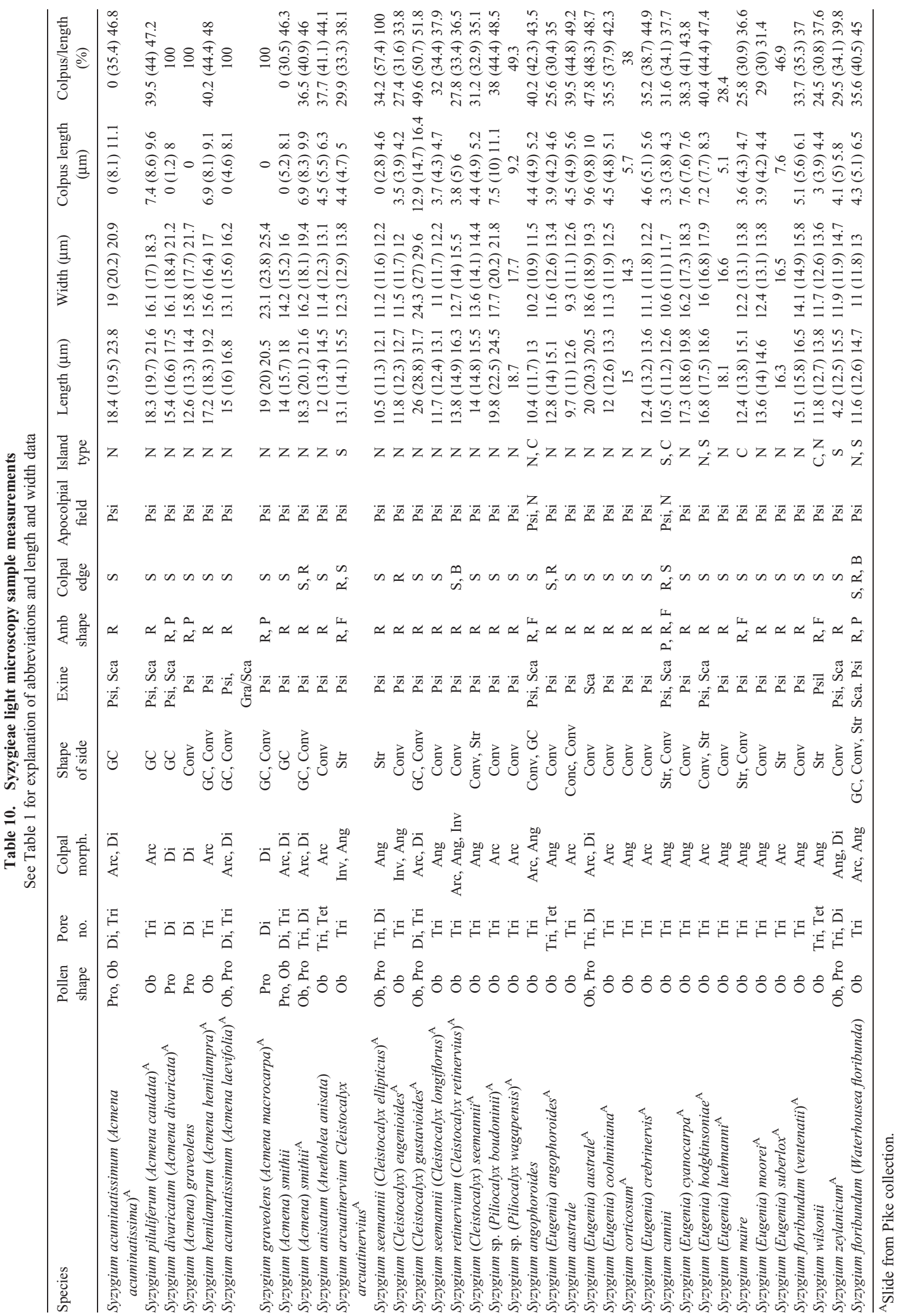


were smooth or rough and a psilate apocolpial field was present. Pollen length ranged from 15.9 to $17.2 \mu \mathrm{m}$. Colpus/length ratio ranged from 56.3 to $59.9 \%$.

LM: exine of Phymatocarpus was scabrate. Pollen sides were straight and colpal morphology was syncolpate. Pollen ambs were pointed or round, colpal edges were smooth and the apocolpial field was psilate. Pollen length ranged from 20.3 to $25.6 \mu \mathrm{m}$. Colpus/length ratio ranged from 52.2 to $56.8 \%$.

\section{Genus Regelia}

Number of species: 5 .

Distribution: south-western Australia.

Species examined: SEM - 1; LM - 2 (3 taxon).

Previous pollen studies: Pike (1956).

Images: SEM polar view - Fig. 4o; SEM exine pattern - Fig. $6 c$; LM polar view - Fig. $9 h-j$.

SEM: Regelia pollen were tricolporate with a verrucate exine. Pollen sides were concave and colpal morphology was syncolpate. Pollen ambs were round or occasionally flat, colpal edges were smooth and the apocolpial field was psilate. Pollen length ranged from 17.3 to $20.7 \mu \mathrm{m}$. Colpus/length ratio ranged from 53.5 to $59.5 \%$.

LM: the exine of Regelia was psilate or scabrate. Pollen sides were straight and occasionally concave and colpal morphology was parasyncolpate with angular colpi or parasyncolpate with arcuate colpi, tending to be almost syncolpate, as exemplified by the pollen of $R$. inops. Pollen ambs were round, colpal edges were smooth and the apocolpial field was psilate. Pollen length ranged from 26.1 to $46.7 \mu \mathrm{m}$. Colpus/length ratio ranged from 29.9 to $56.9 \%$.

\section{Tribe Osbornieae}

Osbornieae is monotypic and contains the mangrove species Osbornia octodonta, which is found in northern Australia and the Philippines. Pollen measurements for Osbornieae are summarised in Tables 7 and 8 .

\section{Genus Osbornia}

Number of species: 1.

Distribution: northern Australia and Philippines.

Species examined: SEM - 1; LM - 1 (2 specimens).

Previous pollen studies: Pike (1956); Patel et al. (1984).

Images: SEM polar view - Fig. 4p; SEM exine pattern - Fig. $6 d$; SEM equatorial view - Fig. $7 e$; LM polar view - Fig. $9 k, l$.

SEM: Osbornia pollen were tricolporate, or sometimes tetracolporate, with a consistent rugulate exine. Pollen sides were straight and colpal morphology was parasyncolpate with
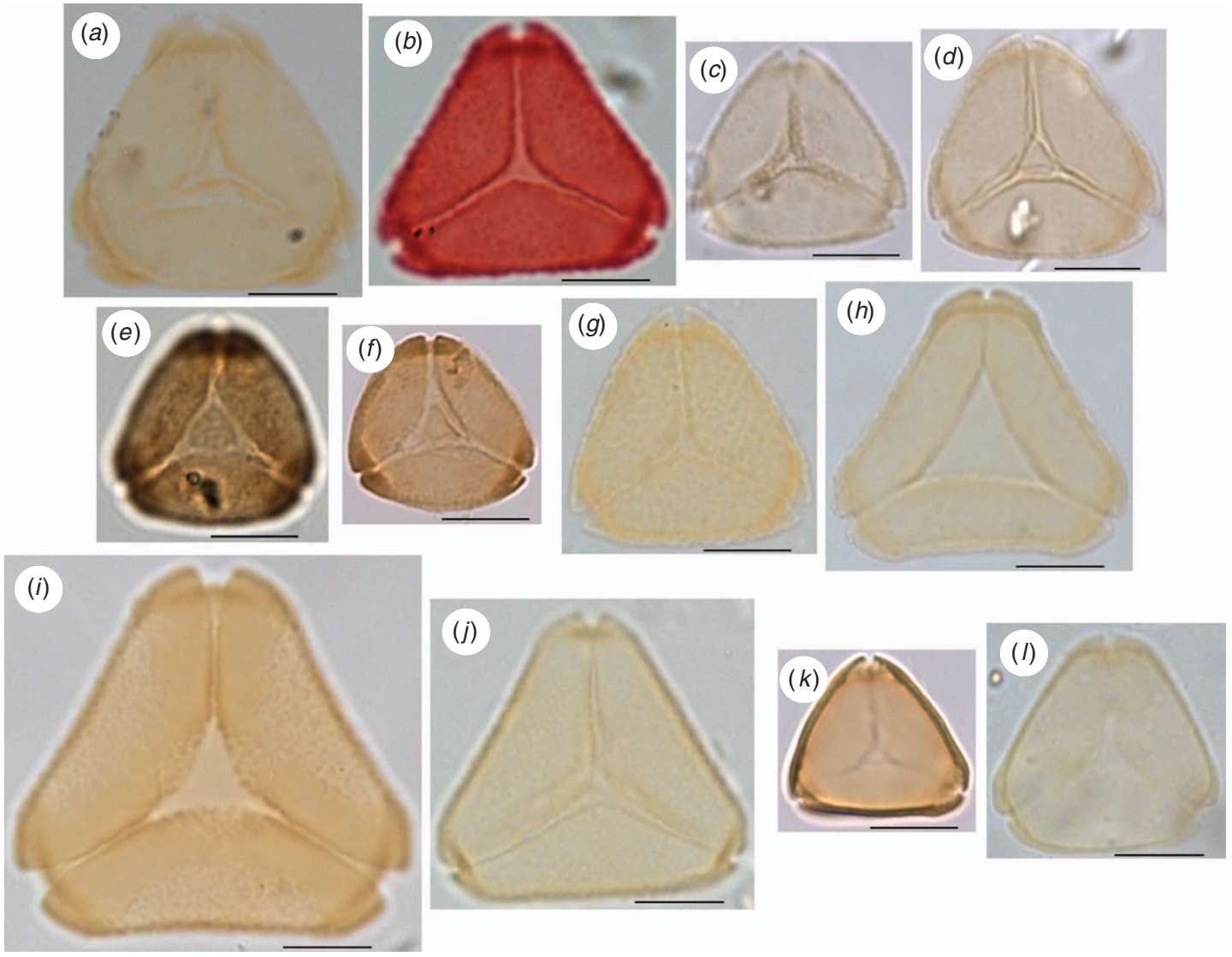

Fig. 9. Polar view of Melaleuceae and Osbornieae as viewed under light microscope. Scale bar $=10 \mu \mathrm{m}$. (a) Melaleuca radula*, (b) M. squamea*, (c) M. squarrosa*, (d) M. squarrosa*, (e) M. steedmanii, (f) M. viridiflora, (g) Phymatocarpus porphyrocephalus*, (h) Regelia ciliata*, (i) R. grandiflora*, (j) R. inops*, $(k)$ Osbornia octodonta and $(l) O$. octodonta*. Slides indicated with asterisk are from Pike collection. 
angular colpi. Pollen length ranged from 14.6 to $16 \mu \mathrm{m}$. Colpus/ length ratio ranged from 40.9 to $59.2 \%$.

LM: exine patterns of Osbornia were psilate. Pollen sides ranged from straight to convex and colpal morphology was syncolpate in pollen prepared for the present study and parasyncolpate with angular colpi in pollen from the Pike collection slide. The majority of pollen lacked a polar island, but a small number of grains had a small irregular apocolpial island. Pollen length ranged from 16.6 to $24.6 \mu \mathrm{m}$. Colpus/length ratio ranged from 35.7 to $48.5 \%$.

\section{Tribe Syzygieae}

Taxa of Syzygieae occur in Australia, New Zealand, Malesia, southern Asia, India, southern China, Africa and many South Pacific islands (especially the Solomon Islands, New Caledonia, Vanuatu and Fiji). It is one of six higher-level Myrtaceae taxa that contain species producing fleshy fruit, the others being
Psiloxyloideae (Psiloxylon), Leptospermeae (Kunzea pomifera and Leptospermum semibaccatum), Myrteae, Lophostemoneae (Kjellbergiodendron) and Tristanieae (Xanthomyrtus) (Wilson 2011). Syzygieae species occur predominantly in rainforest, woodlands and seasonally dry monsoonal forest. There is now only one genus in Syzygieae, after reclassification by Craven and Biffin (2010) on the basis of an analysis of DNA sequence data. For ease of reference to past studies, we have used several of the previously recognised genera of Syzygieae for presentation of the pollen descriptions. Pollen measurements for Syzygieae are summarised in Tables 9 and 10.

\section{Genus Acmena}

Number of species: $~ 39$.

Distribution: northern and eastern Australia, Malesia, South-east Asia, southern China and the Solomon Islands.

Species examined: SEM - 4; LM - 8 (9 samples).

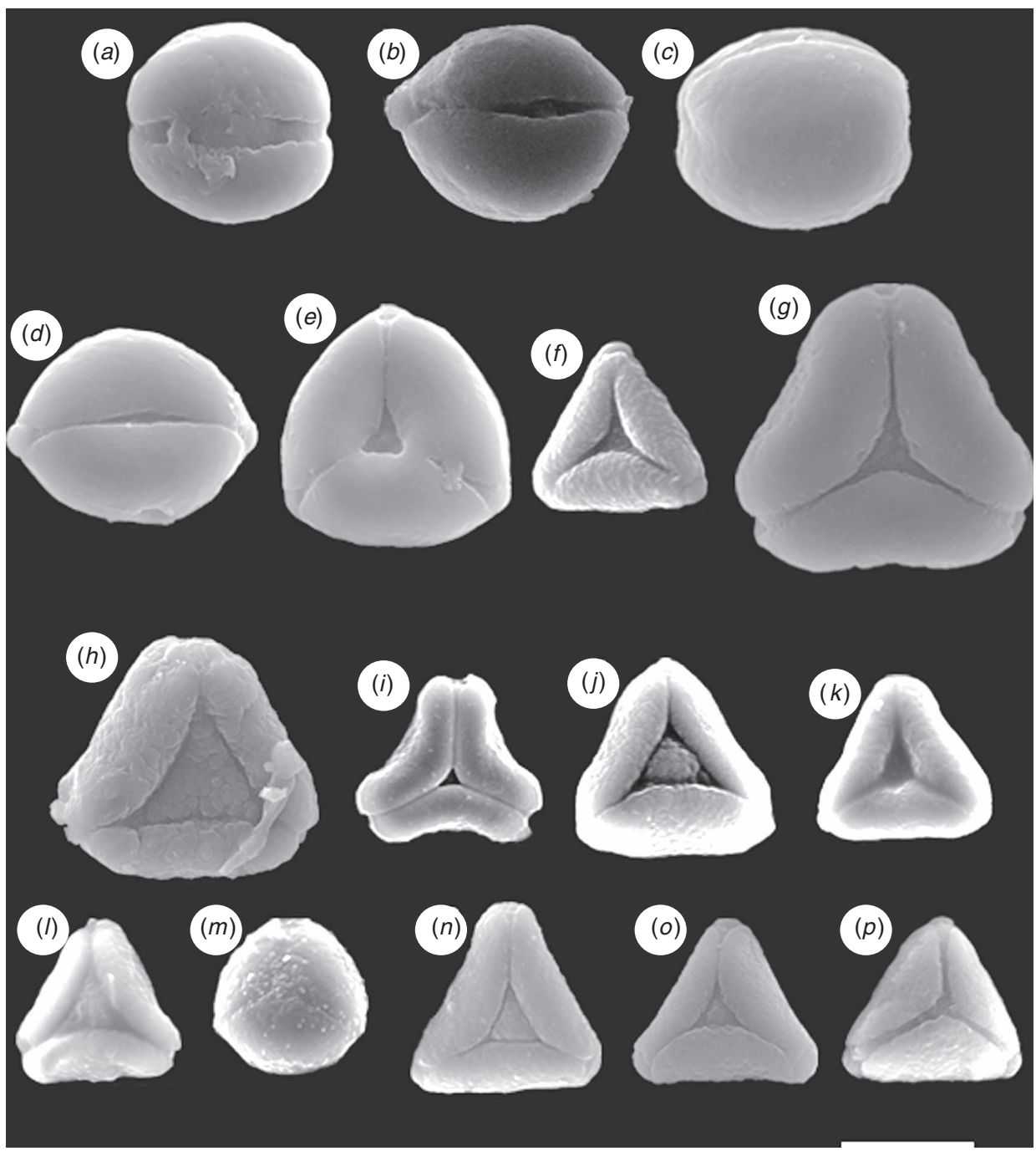

Fig. 10. Polar view of Syzygieae under scanning electron microscope. Scale bar $=10 \mu \mathrm{m}$. (a) Syzygium divaricatum (Acmena divaricata), (b) S. (Acmena) graveolens, (c) S. mackinnonianum (Acmena mackinnoniana), (d) S. (Acmena) smithii, (e) S. (Acmena) smithii, ( $f$ ) S. anisatum (Anetholea anisata), (g) S. sp. (Piliocalyx boudoninii), (h) S. aromaticum, (i) S. australe, (j) S. claviflorum, (k) S. cumini, (l) S. eucalyptoides, (m) S. samarangense, (n) S. wilsonii, (o) S. floribundum (Waterhousea floribunda) and (p) S. hedraiophyllum (Waterhousea hedraiophylla). 
Previous pollen studies: Pike (1956).

Images: SEM polar view - Fig. 10a-e; SEM exine pattern Fig. $11 a-d$; SEM equatorial view - Fig. $13 a, b$; LM polar view - Fig. $14 a-m$.

SEM: Acmena pollen were dicolporate in the majority of species, except for $A$. smithii, which produced an equal proportion of dicolporate and tricolporate pollen. A psilate/rugulate exine was observed on all grains. Pollen sides were convex or sometimes greatly convex and colpal morphology was monocolpate or parasyncolpate with angular or arcuate colpi. Pollen ambs were round or sometimes pointed, colpal edges were smooth or rough and the apocolpial field was psilate. Pollen length ranged from 15 to $18.3 \mu \mathrm{m}$ Colpus/length ratio ranged from 33 to $100 \%$.

LM: the exine of Acmena was psilate, scabrate or, less often, granulate/scabrate. Either dicolporate or tricolporate pollen were observed in Acmena LM samples. Three species, A. acuminatissima, A. laevifolia and $A$. smithii produced pollen that were both dicolporate and tricolporate. Pollen sides were greatly convex or convex and colpal morphology was monocolpate, or parasyncolpate with arcuate colpi. Pollen

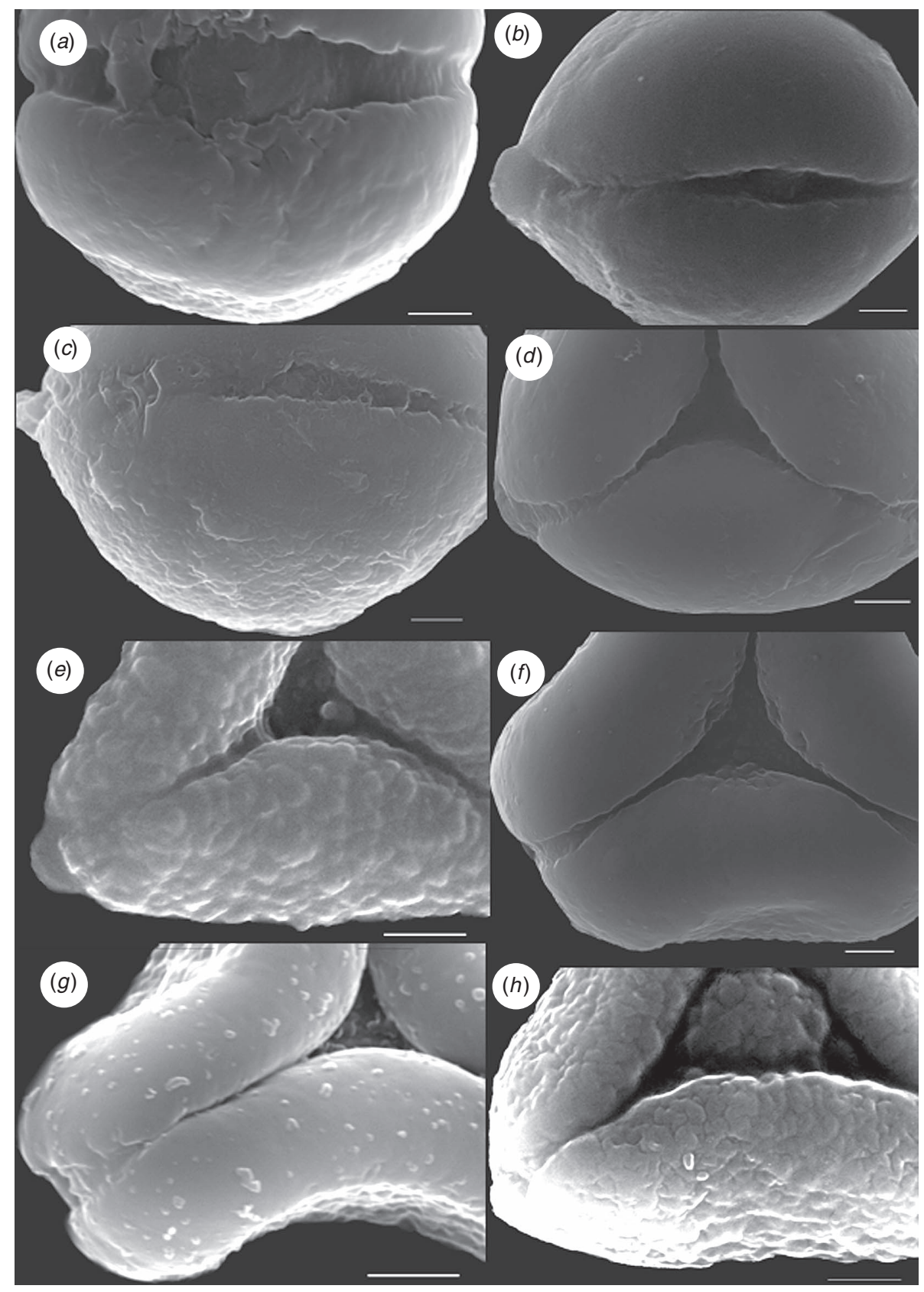

Fig. 11. Exine pattern of Syzygieae under scanning electron microscope. Scale bar $=2 \mu \mathrm{m}$. (a) Syzygium divaricatum (Acmena divaricata), (b) $S$. (Acmena) graveolens, (c) S. mackinnonianum (Acmena mackinnoniana), (d) S. (Acmena) smithii, (e)S. anisatum (Anetholea anisata), $(f)$ Piliocalyx boudoninii, $(g)$ Syzygium australe and (h) S. claviflorum. 
ambs were round or pointed, colpal edges were smooth and the apocolpial field pattern was psilate. Pollen length ranged from 12.6 to $23.8 \mu \mathrm{m}$. Colpus/length ratio ranged from 36.5 to $100 \%$.

\section{Genus Anetholea}

Number of species: 1.

Distribution: eastern Australia.

Species examined: SEM -1; LM - 1 .

Previous pollen studies: none.

Images: SEM polar view-Fig. 10f; SEM exine pattern-Fig. 11e; LM polar view - Fig. $14 n$.

SEM: Anetholea pollen were tricolporate with a granulate exine. Pollen sides were convex or straight, and the colpal morphology was parasyncolpate with arcuate colpi. Pollen ambs were round or pointed, colpal edges were smooth and the apocolpial field was scabrate or psilate. Small apocolpial islands were observed on most grains. Polar length ranged from 11.7 to $12.7 \mu \mathrm{m}$. Colpus/ length ratio ranged from 54.1 to $56.5 \%$.

LM: exine patterns of Anetholea were psilate. Most grains were tricolporate, or on rare occasions, tetracolporate. Pollen sides were convex and colpal morphology was parasyncolpate with arcuate colpi. Pollen ambs were round, colpal edges were smooth and the apocolpial field was psilate. Pollen length ranged from 12 to $14.5 \mu \mathrm{m}$. Colpus/length ratio ranged from 37.7 to $44.1 \%$.

\section{Genus Cleistocalyx}

Number of species: $\sim 33$.

Distribution: Pacific Islands (especially New Caledonia and Fiji), Australia, Malesia, and South-east Asia.

Species examined: SEM - not observed; LM -7.

Previous pollen studies: Pike (1956); Patel et al. (1984).

Images: LM polar view - Fig. 14o-w.

LM: Cleistocalyx pollen were tricolporate, except for some grains of $C$. ellipticus and $C$. gustavoides, which were dicolporate. The exine of all grains was psilate. Pollen sides were convex or straight and, less often, greatly convex. Colpal morphology was parasyncolpate with arcuate, inverse arcuate or angular colpi, except for dicolporate grains that had colpi that were fused and presented the appearance of a single colpus. Pollen ambs were round and colpal edges were mostly smooth, but were

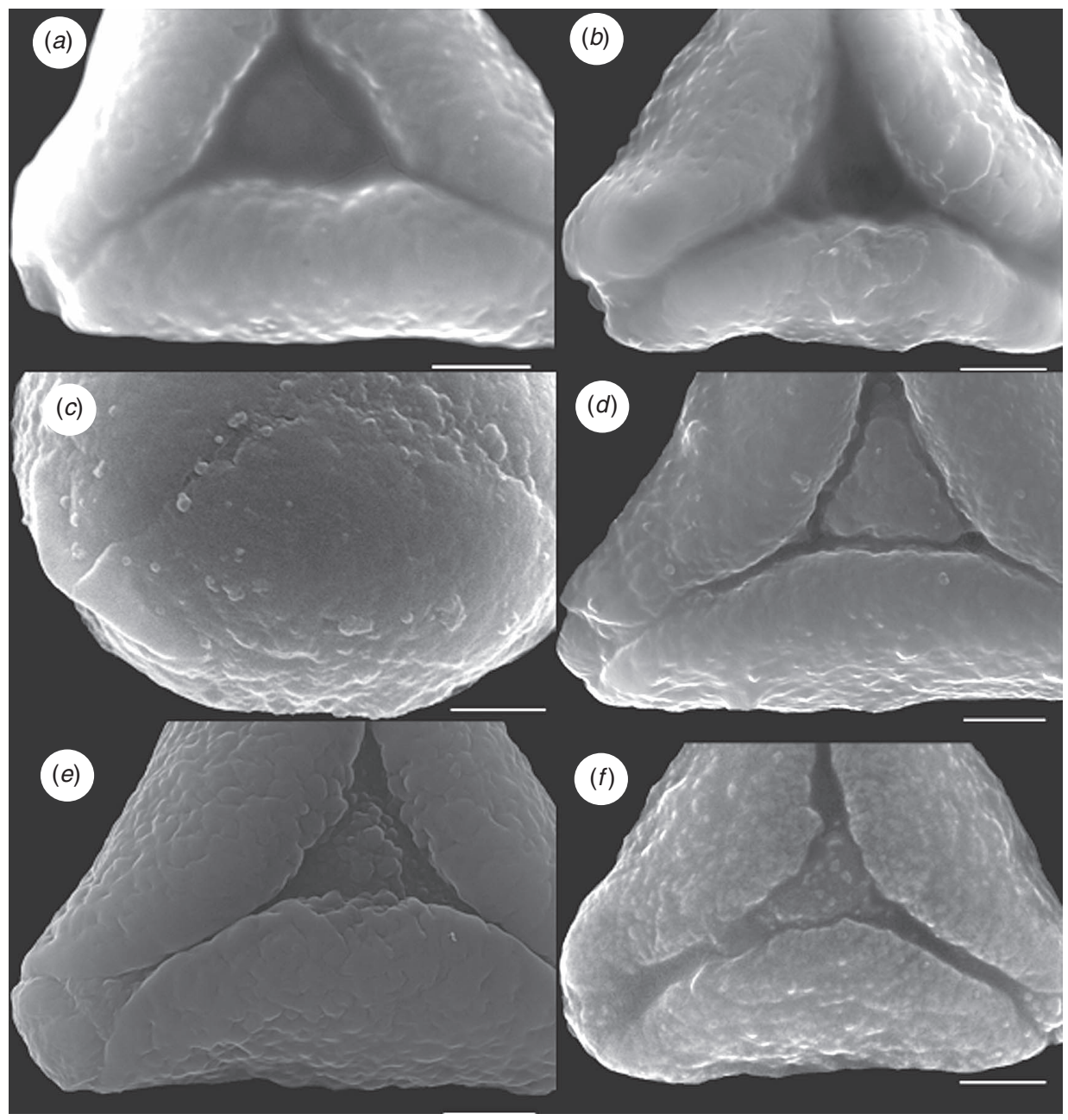

Fig. 12. Exine pattern 2 of Syzygieae under scanning electron microscope. Scale bar $=2 \mu \mathrm{m}$. (a) Syzygium cumini, (b) S. eucalyptoides, (c) S. samarangense, (d) S. wilsonii, (e) S. floribundum (Waterhousea floribunda) and (f) S. hedraiophyllum (Waterhousea hedraiophylla). 
occasionally rough or broken, and the apocolpial field was psilate. All species lacked an apocolpial island, except for C. arcuatinervius, which had a small apocolpial island. Pollen length ranged from 10.5 to $16.3 \mu \mathrm{m}$. Colpus/length ratio ranged from 27.4 to $100 \%$.

\section{Genus Piliocalyx}

Number of species: 20 .

Distribution: New Caledonia, Vanuatu and Fiji.

Species examined: SEM -1; LM - 2 .

Previous pollen studies: Pike (1956).

Images: SEM polar view - Fig. 10g; SEM exine pattern-Fig. 11f; SEM equatorial view - Fig. 13c; LM polar view - Fig. 14ii, jj.

SEM: Piliocalyx pollen were tricolporate, or less often tetracolporate, and the exine was psilate/rugulate. Pollen sides were straight or concave and colpal morphology was parasyncolpate with arcuate colpi. Pollen ambs were round, colpal edges were smooth and the apocolpial field was psilate or scabrate. Pollen length ranged from 11.7 to $12.7 \mu \mathrm{m}$. Colpus/ length ratio ranged from 35.7 to $43.9 \%$.

LM: the exine of Piliocalyx was psilate. Pollen sides were convex and colpal morphology was parasyncolpate with arcuate colpi. Pollen ambs were round, colpal edges were smooth and the apocolpial field was psilate. Pollen length ranged from 18.7 to $24.5 \mu \mathrm{m}$. Colpus/length ratio ranged from 38 to $49.3 \%$.

\section{Genus Syzygium}

Number of species: $\sim 1200$.

Distribution: Australia, Pacific Islands (especially the Solomon Islands, New Caledonia, Vanuatu and Fiji), Malesia, South-east Asia, southern Asia, New Zealand, Africa, Madagascar and the Mascarenes.

Species examined: SEM - 7; LM - 15 (17 samples).

Previous pollen studies: Pike (1956); McIntyre (1963); Moar (1993); Premathilake and Nilsson (2001); Parnell (2003); Fujiki and Ozawa (2007).

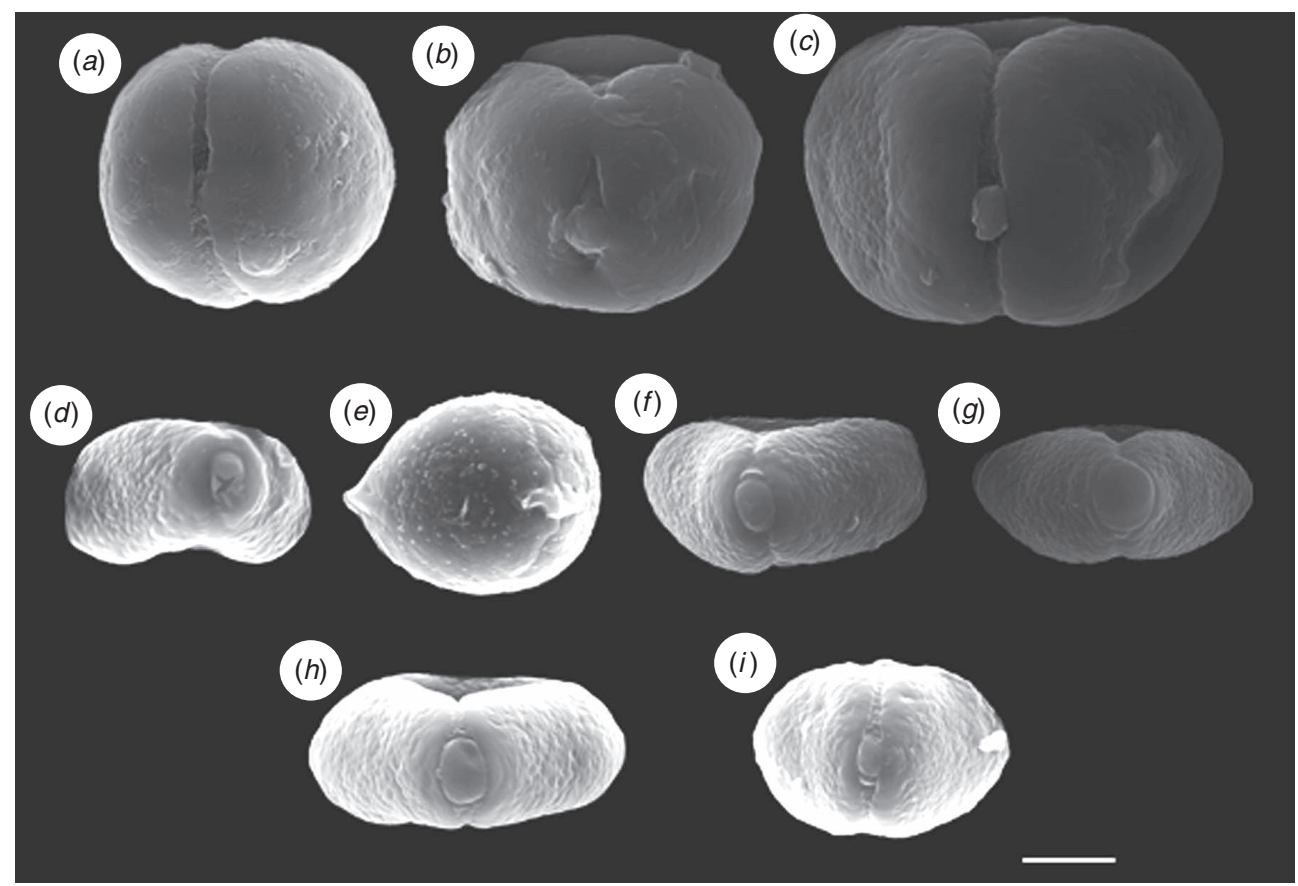

Fig. 13. Equatorial view of Syzygieae, Backhousieae and Metrosiderea under scanning electron microscope. Scale bar $=5 \mu \mathrm{m}$. (a) Syzygium mackinnonianum (Acmena mackinnoniana), (b) S. (Acmena) smithii, (c) Piliocalyx boudoninii, (d) Syzygium cumini, (e) S. samarangense, (f) S. wilsonii, (g) S. floribundum (Waterhousea floribunda), (h) Backhousia citriodora and (i) Metrosideros carmine.

Fig. 14. Polar view of Syzygieae as viewed under light microscope. Scale bar $=10 \mu \mathrm{m}$. (a) Syzygium acuminatissimum (Acmena acuminatissima)*, (b) S. acuminatissimum (Acmena acuminatissima)*, (c) S. piluliferum (Acmena caudata)*, (d) S. divaricatum (Acmena divaricata)*, (e) S. divaricatum (Acmena divaricata)*, ( $f) S$. (Acmena) graveolens, $(g)$ S. hemilamprum (Acmena hemilampra)*, $(h)$ S. acuminatissimum (Acmena laevifolia)*, (i) S. acuminatissimum (Acmena laevifolia)*, (j) S. graveolens (Acmena macrocarpa)*, (k) S. (Acmena) smithii, (l) S. (Acmena) smithii, (m) S. (Acmena) smithii*, (n) S. anisatum (Anetholea anisata), (o) S. arcuatinervium (Cleistocalyx arcuatinervius)*, $(p)$ S. seemannii $\left(\right.$ Cleistocalyx ellipticus)* ${ }^{*},(q)$ S. seemannii (Cleistocalyx ellipticus)*, $(r)$ S. (Cleistocalyx) eugenioides*, $(s)$ S. (Cleistocalyx) gustavioides*, $(t)$ S. (Cleistocalyx) gustavioides*, $(u)$ S. seemannii $($ Cleistocalyx longiflorus)*, (v) S. retinervium (Cleistocalyx retinervius)*, (w) S. (Cleistocalyx) seemannii*, (x) S. (Eugenia) angophoroides*, (y) S. (Eugenia) angophoroides*, (z) S. (Eugenia) australis*, (aa) S. (Eugenia) australis*, (bb) S. (Eugenia) coolminiana*, (cc) S. (Eugenia) crebrinervis*, (dd) S. (Eugenia) cyanocarpa*, (ee) S. (Eugenia) hodgkinsoniae*, (ff) S. (Eugenia) luehmanni*, (gg) S. (Eugenia) moorei*, (hh) S. (Eugenia) suberlox*, (ii) S. sp. (Piliocalyx boudoninii)*, (jj) S. sp. (Piliocalyx wagapensis)*, (kk) S. angophoroides, (ll) S. australe, (mm) S. corticosum*, (nn) S. cumini, (oo) S. maire, (pp) S. floribundum (ventenatii)*, (qq) S. wilsonii, (rr) S. zeylanicum* and (ss) S. floribundum (Waterhousea floribunda). Slides indicated with asterisk are from Pike collection. 

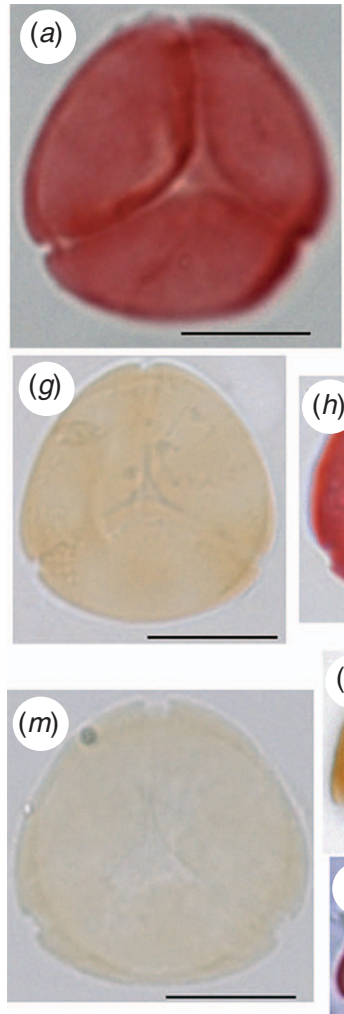

(n)
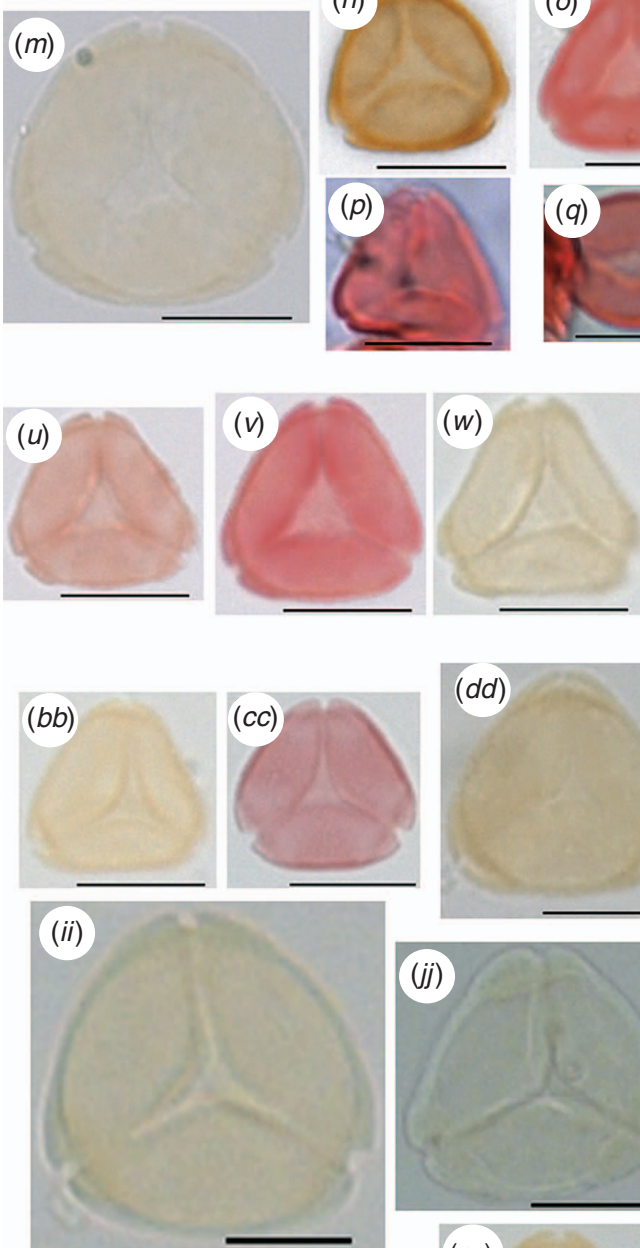

$(d d)$
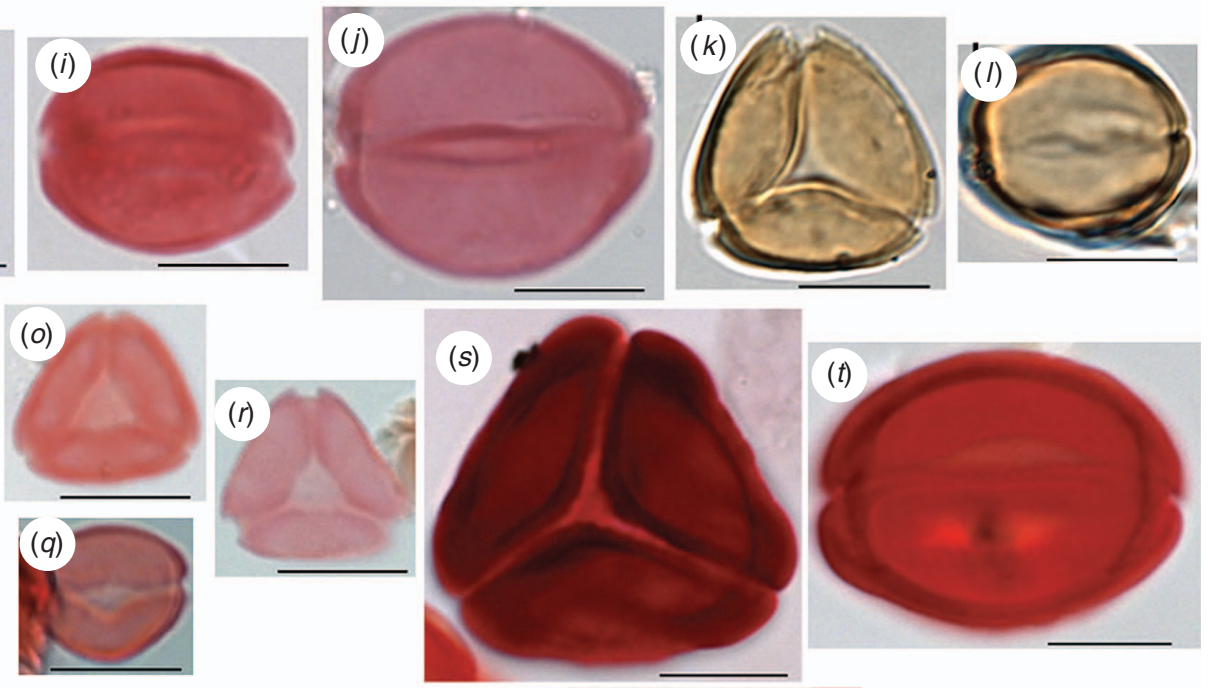

(z)
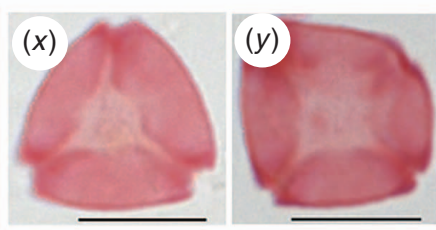

(aa)
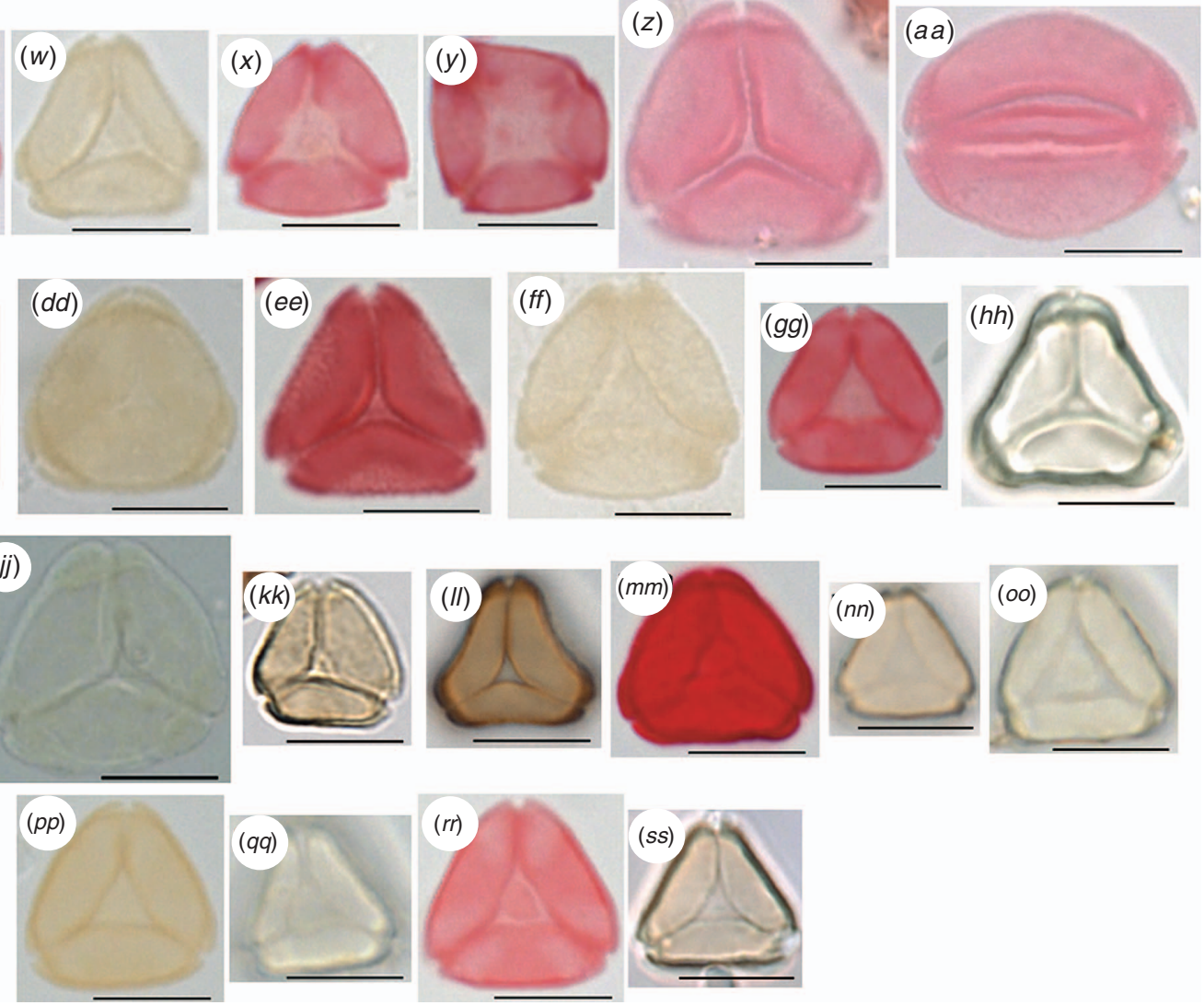
Images: SEM polar view - Fig. 10h- $n$; SEM exine pattern Figs $11 g, h, 12 a-d$; SEM equatorial view - Fig. $13 d-f ;$ LM polar view - Fig. 14kk-rr.

SEM: Syzygium pollen were tricolporate with a psilate/rugulate or verrucate/scabrate exine. Pollen sides were convex, straight or concave and the colpal morphology was parasyncolpate with angular or arcuate colpi. Pollen ambs were round or pointed, colpal edges were smooth, broken or rough and the apocolpial field was psilate or less often scabrate. Closely fitting apocolpial islands were observed on half of the Syzygium species. Pollen length ranged from 11.3 to $18.4 \mu \mathrm{m}$. Colpus/length ratio ranged from 24.2 to $57.6 \%$.

LM: the exine of Syzygium was psilate or, less commonly, scabrate. Most pollen were tricolporate, but four species produced occasional tetracolporate or dicolporate grains. Pollen sides were convex or straight, and colpal morphology was parasyncolpate with angular or arcuate colpi. Pollen ambs were round, or lest often flat or pointed, colpal edges were smooth or sometimes rough, and the apocolpial field was psilate. Some species had closely fitting or small irregular apocolpial islands. Pollen length ranged from 10.4 to $20.5 \mu \mathrm{m}$. Colpus/length ratio ranged from 24.5 to $49.2 \%$.

\section{Genus Waterhousea}

Number of species: 4.

Distribution: eastern Australia.

Species examined: SEM -2; LM - 1 .

Previous pollen studies: none.

Images: SEM polar view - Fig. 10o, $p$; SEM exine pattern Fig. $12 e, f$; SEM equatorial view - Fig. 13g; LM polar view Fig. 14ss.

SEM: Waterhousea pollen were tricolporate with a rugulate or verrucate/scabrate exine. Pollen sides were straight, or sometimes convex, and colpal morphology was parasyncolpate with arcuate colpi. Pollen ambs were round or pointed, colpal edges were rough or smooth and the apocolpial field was psilate or scabrate. No apocolpial islands were observed on W.hedraiophylla grains, whereas small irregular or globular islands occurred in $W$. floribunda. Pollen length ranged from 11.4 to $12.2 \mu \mathrm{m}$. Colpus/length ratio ranged from 39.5 to $51.4 \%$.

LM: exine patterns of Waterhousea were scabrate or psilate. Pollen sides were greatly convex, convex or straight and colpal morphology was parasyncolpate with arcuate or angular colpi. Pollen ambs were round and occasionally pointed. Colpal edges were smooth or rough and the apocolpial field was psilate. The majority of pollen grains lacked an apocolpial island; however, some small irregular islands were seen. Pollen length ranged from 11.6 to $14.7 \mu \mathrm{m}$. Colpus/length ratio ranged from 35.6 to $45 \%$.

\section{Summary of tribes Backhousieae, Melaleuceae,} Metrosidereae, Osbornieae and Syzygieae

\section{Backhousieae}

Backhousieae pollen were generally parasyncolpate with arcuate colpi, and occasionally syncolpate (Choricarpia). The difference in exine patterns clearly separated the pollen of the two
Backhousieae genera, with Backhousia being psilate and having insignificant patterns, whereas, in contrast, Choricarpia was scabrate and highly ornate. Apocolpial islands were not seen in SEM but in LM one Choricarpia species (C. leptopetala) had closely fitting apocolpial islands. There was no major difference in pollen length within the tribe $(\sim 14 \mu \mathrm{m})$.

\section{Melaleuceae}

Melaleuceae pollen were most commonly parasyncolpate with angular colpi; however, taxa belonging to some former genera had arcuate colpi or were syncolpate (Calothamnus, Eremaea, Phymatocarpus and Regelia), which differed from most members of Melaleuceae, but were not dissimilar to pollen produced by taxa of Leptospermeae and Chamelaucieae. Exine patterns were primarily rugulate, but there were occasional occurrences of more ornate granulate/scabrate or verrucate/ scabrate patterns. All Melaleuca species observed by SEM had closely fitting islands, as well as did Callistemon and Lamarchea species. Beaufortia pollen had small irregular apocolpial islands, whereas the other Melaleuceae genera pollen lacked an island. Pollen size was variable in Melaleuceae, with smaller-sized pollen grains occurring in Callistemon, Melaleuca and Calothamnus, larger-sized pollen occurring in Beaufortia, Lamarchea and Regelia $(\sim 17-20 \mu \mathrm{m})$ and very large pollen were observed in LM samples of Eremaea $(\sim 25 \mu \mathrm{m})$.

\section{Metrosidereae}

Metrosidereae pollen were parasyncolpate with angular colpi (similar to the pollen of some Melaleuceae), with the exception of Tepualia, which was dicolporate. Most pollen had a rugulate exine, with some pollen appearing verrucate or vermiculate. All Metrosidereae pollen, except Tepualia, possessed an apocolpial island, and closely fitting was the most common type. Pollen size was variable, but most recorded pollen lengths were average size for Myrtaceae pollen $(\sim 15 \mu \mathrm{m})$.

\section{Osbornieae}

Osbornieae is monotypic and very little variation was observed. However, the two LM samples used for the present study displayed different colpal morphologies. Pollen of the Pike collection slide appeared parasyncolpate with arcuate colpi and the pollen prepared for the present study had pollen that were syncolpate. The Osbornieae exine pattern was rugulate, which was commonly observed in many other Myrtaceae tribes. Pollen size varied between microscopy methods and among LM samples, with the pollen observed by SEM being about $15 \mu \mathrm{m}$, whereas those in LM samples ranged from 17 to $22 \mu \mathrm{m}$.

\section{Syzygieae}

Syzygieae pollen were most commonly parasyncolpate with arcuate or sometimes angular colpi. Some Acmena species (A. divaricata, A. graveolens, A. mackinnoniana, and A. macrocarpa) had dicolporate pollen, whereas other species (A. acuminatissima, A. laevifolia, and A. smithii) produced pollen that were either dicolporate or tricolporate. Syzygieae exines were consistently psilate or rugulate. Closely fitting pollen apocolpial islands were seen in many Syzygium species and small irregular islands were observed on the pollen of 
Anetholea and Waterhousea. Pollen size was generally consistent within Syzygieae $(\sim 11-13 \mu \mathrm{m})$; however, large pollen were observed in Piliocalyx $(\sim 20 \mu \mathrm{m})$ and in one Cleistocalyx species (C. gustavioides, $\sim 28 \mu \mathrm{m})$.

\section{Discussion}

Distinct pollen morphology in phylogenetic groups

A number of phylogenetic studies of the individual tribes in the present study allows us to compare the association of distinct pollen types or characters with systematic groups (Wright et al. 2000, 2001; Biffin et al. 2006; Cook et al. 2008; Edwards et al. 2010). Similar to the taxa of tribes presented in Thornhill et al. (2012a), most described pollen were parasyncolpate with arcuate or angular colpi, making differentiating pollen among tribes difficult. There was also little variation in pollen size, although some pollen of tribe Melaleuceae species (Beaufortia, Eremaea, Lamarchea and Regelia) appeared moderately larger. Pollen grains of the monophyletic group Metrosideros (including Mearnsia) (Wright et al. 2000, 2001) all had apocolpial islands and this may be of some benefit to New Zealand palynologists because the other endemic New Zealand Myrtaceae taxa, with the exception of Syzygium maire, have morphologically different pollen. However, in comparison with other tribes of Myrtaceae, Metrosideros pollen are not dissimilar to Melaleuceae, Syzygieae, Eucalypteae and Xanthostemoneae. All Callistemon species had large closely fitting apocolpial islands when viewed by LM, similar to previous observations of the genus (Pike 1956; Binder 1978), and island presence appears to be characteristic of this group, although pollen of C. sieberi and C. viridiflorus viewed by SEM did not consistently have this feature. This may be because Callistemon has been shown to be paraphyletic and also nested within Melaleuca (Edwards et al. 2010). The monophyletic group of Beaufortia (Edwards et al. 2010) had pollen that were granulate and had a prominent margo (thickened exine near the colpus and aperture regions). Lamarchea and Regelia pollen were large compared with those of Beaufortia, but also displayed the same prominent margo. The pollen of Calothamnus and Eremaea species appeared similar and all had syncolpate pollen; however, this cannot be linked to a monophyletic clade of Melaleuceae (Edwards et al. 2010).

Within tribe Backhousieae, Choricarpia pollen had a distinctive exine pattern when viewed under SEM, in comparison to its sister genus Backhousia. This pattern was still noticeable in LM but could be confused as scabrate, and its use as a diagnostic character is therefore not as powerful. Dicolporate pollen were observed in two tribes, Metrosidereae (Tepualia) and Syzygieae (Acmena), and this feature may be of systematic value. The dicolporate grains of these two genera were also easily distinguishable. Tepualia grains were small $(10 \mu \mathrm{m})$ in length and had straight sides, compared with those of Acmena which were longer $(15 \mu \mathrm{m})$ and had round convex sides. Dicolporate pollen are also characteristic of Pileanthus (see Thornhill et al. 2012b); however, again, this can be discerned from the other two genera by the fact that the genus has a psilate exine and colpi do not always fuse together to give the appearance of a single colpus. Interestingly, three species of Acmena that produce dicolporate pollen ( $A$. divaricata, A. graveolens and A. mackinnoniana) form a monophyletic group in Biffin et al's (2006) Syzygieae phylogeny, that is sister to another group of Acmena species that produces both dicolporate and tricolporate pollen species (A. acuminatissima and $A$. smithii), suggesting that a total shift to dicolporate grains has been made within part of the Acmena clade.

The exine pattern did not show much variability in the observed tribes. One feature that may have phylogenetic significance is the psilate exine of Acmena and Piliocalyx; the latter of these two genera nest within the traditional circumscription of Acmena (Biffin et al. 2006) but is sister to Acmena sensu stricto in the classification of Craven and Biffin (2010). Very small pollen were observed in many species of Syzygieae; however, they were not consistently observed in the tribe to be of any systematic value.

\section{Pollen types within genera}

\section{Melaleuca}

Different pollen types were observed within Melaleuca. Many species of the M. leucadendra complex (Cook et al. 2008; Edwards et al. 2010) had pollen with large apocolpial islands and appeared similar to pollen of Callistemon. This is interesting, considering the similar 'bottle-brush' floral structure of these two groups, and the shared pollen characters may reflect possible similarities in modes of pollen dispersal or a shared pollinator group. The other main pollen type of Melaleuca was medium-sized, syncolpate pollen with faint granulate patterning (e.g. M. squamea). In light of recent phylogenetic work (Edwards et al. 2010), it appears that the two Melaleuca pollen types are homoplasious within the genus.

\section{Syzygium}

Syzygium pollen, in general, were smaller than pollen from most other tribes of the present study; however, no other characters were useful in delineating the tribe from other Myrtaceae tribes with similar pollen. Apocolpial islands occurred in some members of Syzygieae, but were not consistent in relation to any phylogenetic groups as defined by Biffin et al. (2006); such a lack of correlation has previously been noted by (Parnell 2003). The shape of pollen sides was very variable within Syzygium and this character also appears to not be of any systematic value.

\section{Supplementary Material}

Supplementary Material for this article is available on the Journal's website.

\section{Acknowledgements}

The authors would like to thank the two anonymous reviewers whose comments and additions led to the improvement of the manuscript. Much of the SEM sampling was funded by research grants from the Centre for Archaeological Research (CAR), The Australian National University. The first author would like to thank Drs. Cheng Huang and Frank Brink from the ANU Electron Microscopy Unit for their assistance with SEM work. Drs. Gillian Brown and Andrew Drinnan from the School of Botany, the University of Melbourne, and Dr Ian Thomas from the School of Land and Environment aided in locating and then loaning slides from the Kathleen 
Pike collection. The Directors and/or Curators of the following herbaria are thanked for the opportunity to study specimens in their care: Queensland Herbarium (BRI), Australian National Herbarium (CANB), Northern Territory Herbarium (DNA), National Herbarium Nederland (Leiden) (L), National Herbarium of New South Wales (NSW).

\section{References}

Biffin E, Craven LA, Crisp MD, Gadek PA (2006) Molecular systematics of Syzygium and allied genera (Myrtaceae): evidence from the chloroplast genome. Taxon 55, 79-94. doi:10.2307/25065530

Biffin E, Lucas EJ, Craven LA, da-Costa IR, Harrington MG, Crisp MD (2010) Evolution of exceptional species richness among lineages of fleshy-fruited Myrtaceae. Annals of Botany 106, 79-93. doi: $10.1093 / \mathrm{aob} / \mathrm{mcq} 088$

Binder RM (1978) 'Stratigraphy and pollen analysis of a peat deposit, Bunyip Bog, Mt Buffalo, Victoria.' (Department of Geography, Monash University: Melbourne)

Boyd WE (1992) 'A pollen flora of the native plants of South Australia and southern Northern Territory, Australia.' (The University of Adelaide: Adelaide)

Chalson JM, Martin HA (1995) The pollen morphology of some co-occurring species of the family Myrtaceae from the Sydney region. Proceedings of the Linnean Society of New South Wales 115, 163-191.

Cook LG, Morris DC, Edwards RD, Crisp MD (2008) Reticulate evolution in the natural range of the invasive wetland tree species Melaleuca quinquenervia. Molecular Phylogenetics and Evolution 47, 506-522. doi:10.1016/j.ympev.2008.02.012

Craven LA, Biffin E (2010) An infrageneric classification of Syzygium (Myrtaceae). Blumea 55, 94-99. doi:10.3767/000651910X499303

Edwards RD, Craven LA, Crisp MD, Cook LG (2010) Melaleuca revisited: cpDNA and morphological data confirm that Melaleuca L. (Myrtaceae) is not monophyletic. Taxon 59, 744-754.

Fujiki T, Ozawa T (2007) 'The pollen flora of Ryukyu, Japan.' (Aqua Coral Planning: Ginowan City, Okinawa, Japan)

Gadek PA, Martin HA (1981) Pollen morphology in the subtribe Metrosiderinae of the Leptospermoideae (Myrtaceae) and its taxonomic significance. Australian Journal of Botany 29, 159-184. doi:10.1071/BT9810159

Martin HA (1973) Palynology and historical ecology of some cave excavations in Australian-Nullarbor. Australian Journal of Botany 21, 283-316. doi:10.1071/BT9730283
McIntyre DJ (1963) Pollen morphology of New Zealand species of Myrtaceae. Transactions of the Royal Society of New Zealand 2, 83-107.

Moar NT (1993) 'Pollen grains of New Zealand dicotyledonous plants.' (Manaaki Whenua Press: Lincoln, New Zealand)

Parnell J (2003) Pollen of Syzygium (Myrtaceae) from SE Asia, especially Thailand. Blumea 48, 303-317.

Patel VC, Skvarla JJ, Raven PH (1984) Pollen characters in relation to the delimitation of Myrtales. Annals of the Missouri Botanical Garden 71, 858-969. doi:10.2307/2399170

Pike KM (1956) Pollen morphology of Myrtaceae from the south-west Pacific area. Australian Journal of Botany 4, 13-53. doi:10.1071/BT9560013

Premathilake R, Nilsson S (2001) Pollen morphology of endemic species of the Horton Plains National Park, Sri Lanka. Grana 40, 256-279. doi:10.1080/00173130152987508

Thornhill AH, Hope G, Craven LA, Crisp MD (2012a) Pollen morphology of the Myrtaceae. Part 1: tribes Eucalypteae, Lophostemoneae, Syncarpieae, Xanthostemoneae and subfamily Psiloxyloideae. Australian Journal of Botany 60. doi:10.1071/BT11174

Thornhill AH, Wilson PG, Drudge J, Barrett MD, Hope GS, Craven LA, Crisp MD (2012b) Pollen morphology of the Myrtaceae. Part 3: tribes Chamelaucieae, Leptospermeae and Lindsayomyrteae. Australian Journal of Botany 65. doi:10.1071/BT11176

Wilson PG (2011) Myrtaceae. In 'The families and genera of vascular plants. Vol. X. Flowering plants Eudicots: Sapindales, Cucurbitales, Myrtaceae'. (Ed. K Kubitzki) pp. 212-271. (Springer-Verlag: Heidelberg)

Wilson PG, O’Brien MM, Heslewood MM, Quinn CJ (2005) Relationships within Myrtaceae sensu lato based on a matK phylogeny. Plant Systematics and Evolution 251, 3-19. doi:10.1007/s00606-004-0162-y

Wright SD, Keeling DJ, Ashton FG, Dawson JW, Gardner RC (2000) Phylogenetic analyses of New Caledonian Metrosideros and Carpolepis (Myrtaceae) from nrDNA (ITS) sequences. Australian Systematic Botany 13, 919-926. doi:10.1071/SB00009

Wright SD, Yong CG, Wichman SR, Dawson JW, Gardner RC (2001) Stepping stones to Hawaii: a trans-equatorial dispersal pathway for Metrosideros (Myrtaceae) inferred from nrDNA (ITS plus ETS). Journal of Biogeography 28, 769-774. doi:10.1046/j.1365-2699.2001.00605.x

Zhou MM, Heusser CJ (1996) Late-glacial palynology of the Myrtaceae of southern Chile. Review of Palaeobotany and Palynology 91, 283-315. doi:10.1016/0034-6667(95)00076-3 